\title{
PAINTED DEPICTION OF GENIUS OF SOPIANAE
}

\author{
ANITA KIRCHHOF \\ Aquincum Museum and Archaeological Park \\ 135 Szentendrei út, H-1031 Budapest, Hungary \\ a.kirchhof@freemail.hu
}

\begin{abstract}
A preceding archeological excavation opened the way for the recovery of a larger building complex on Kossuth Square, Pécs. A wall-painting islet consisting of fragmented, but contigious pieces was unearthed, was a part of a larger painting decorating the northern wall of the room of the building complex in Severan times. The half man size figure surviving in bust was created with a brilliant brushwork using rich colours on a white background. The figure can be identified as Genius based on his attributes (the cornucopia and the crown) and the inscription of the painting. This paper discusses reconstruction possibilities of the wall-painting, painting techniques and materials applied, and deals with the possible functions of the room the wall-painting was unearthed in.
\end{abstract}

Keywords: Genius, Sopianae, wall-painting, Roman painting, sanctuary, Pannonia

\section{SITE AND CONDITIONS OF RECOVERY}

In Kossuth Square, Pécs fragments of wall-paintings were found on an excavation prior to construction in 2008. ${ }^{1}$ The excavation was led by Zsolt Tóth ${ }^{2}$ of Janus Pannonius Museum. ${ }^{3}$ Some of the fragments adding up to a larger, contiguous piece were laying upside down. (Figs 1-2) After picking up all pieces, conservation and restoration ${ }^{4}$ followed, an inscription became legible, making clear that the figure depicted on the wall-painting is a genius. ${ }^{5}$ (Fig. 3)

The wall-painting decorated the northern ${ }^{6}$ sidewall of a larger building ${ }^{7}$ datable to the Severan Age (Fig. 4). According to excavation records the upper walls consisted of partly adobe, and of a stone base. ${ }^{8}$ The building tech-

${ }^{1}$ The excavations took place between February 25 and July 22, 2008. The wall-painting was recovered on April 30, 2008 on the northwestern part of the square, from trench no. A/VIII. JPM, Archeological Department inventory number: 2.2.2015. The site, concerning the topography of Sopianae, took place in the eastern part of the settlement, at the eastern front of the late-Roman city-wall. TóтH 2008, 3

${ }^{2}$ I sincerely thank the opportunity of publishing, and the help to write this article to Zsolt Tóth.

${ }^{3}$ Will be referred as JPM in the following text. I would also like to express my thanks the Janus Pannonius Museum for the publication of this study.

${ }^{4}$ The finds were picked up by conservators Éva Horváth, Zsuzsa Horváth, Magdolna Gardánfalviné Kovács between 05.07-08. 2008. A 1:1 scale drawing was made of the wall-painting by Kálmán Szijártó, graphic artist, on location.
${ }^{5}$ Before conservation and restoration of the inscription, the depicted figure was identified as godess Fortuna or Abundantia because of her characteristic cornucopia (horn of plenty). То́тн 2008, 9.

${ }^{6}$ The larger isle like fragment depicting a figural scene, has likely fallen down from the northern wall of the room since it was discovered in the immediate forefront of the northern wall, beside the entrance of the room opened on the northern part of the eastern wall. Based on the kind verbal info of Zs. Tóth.

${ }^{7}$ The building consisted of at least five rooms, only one could be excavated completely, the others having been disturbed throughout modern construtions. То́тн 2008, 9, and according to his kind verbal informations.

${ }^{8}$ The bottom of the wall (dado) consisted of a couple of courses of stone, the upper walls were built of mudbricks. The wallpainting was recovered from under the layer of clay rubble of the mudbricks. Based on the kind verbal info of Zs. Tóth. 


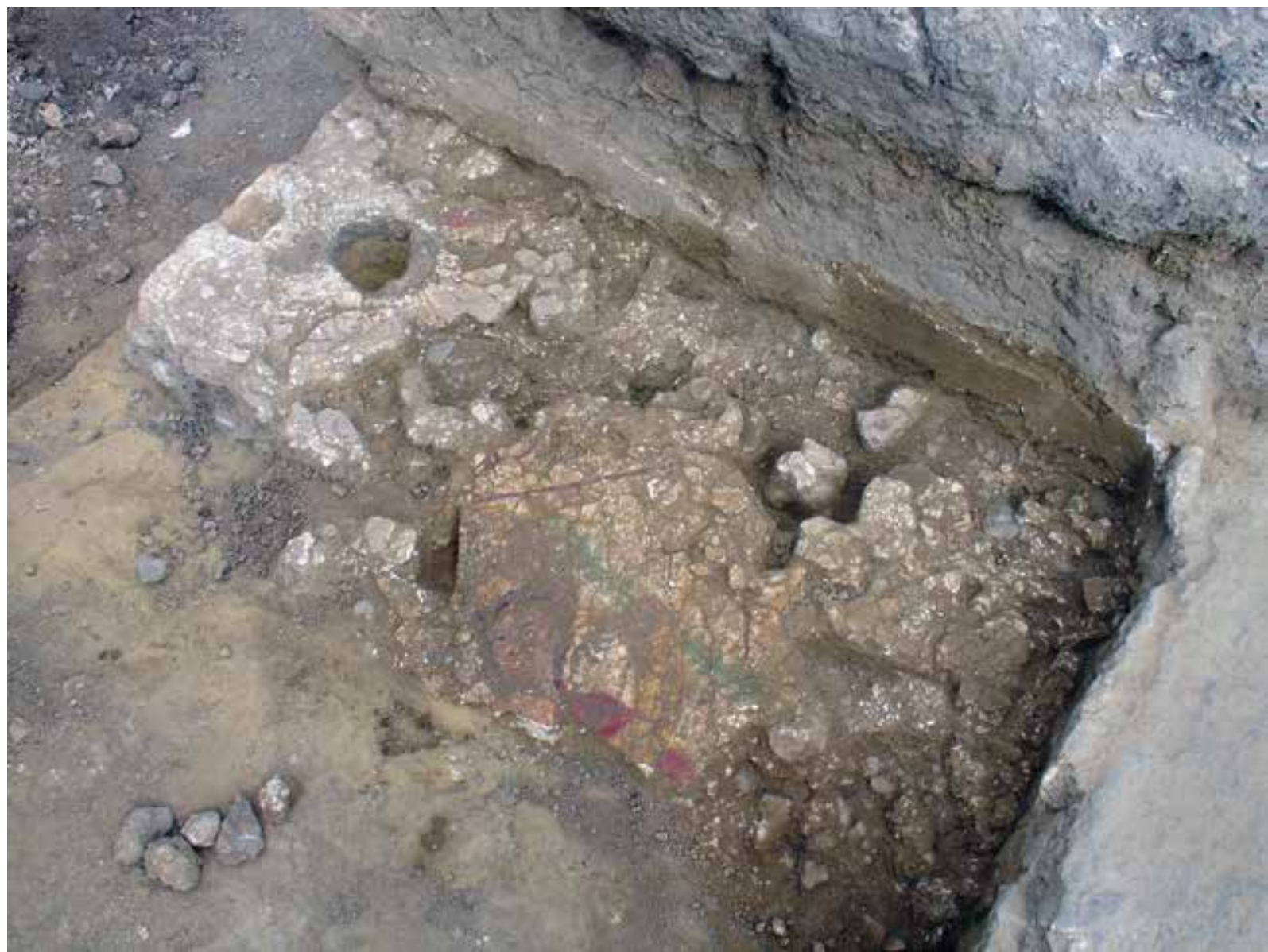

Fig. 1. Larger, isle like wall-painting fragment fallen intact found on the archaeological excavation of Kossuth Square from the south-east (photo: Zsolt Tóth)

nique of the wall structure and body can be considered as general regarding contemporary buildings. ${ }^{9}$ (Fig. 5) The floor of the room was covered with a thin layer of mortar, only observable in patches at the time of the excavation. ${ }^{10}$ The building was restructured at least once and added to throughout its lifetime. ${ }^{11}$ The wall-painting belongs to the last painting period of the building, ${ }^{12}$ no sings of repainting could be detected. The wall-painting was not broken off the wall on purpose, its decay can be linked with the slow natural collapse of the building. ${ }^{13}$ The piece depicting genius being preserved, because of extensive disturbance of later periods, can be considered only of a good luck. ${ }^{14}$ The western part of the building has fallen prey to a modern construction,,$^{15}$ the dimensions of the wall-painted room (the length of the northern and southern sidewalls) can be only guessed. (Fig. 4-5)

${ }^{9}$ See list of sites contemporary with Kossuth Square building on map in the paper (Fig. 5).

${ }^{10}$ Tо́тн 2008, 9. A thin white layer of mortar identified as tread surface was constructed on a hard pebbly bedrock. The courts of stones of the upper wall of the building were built on this layer as well. Based on the kind verbal info of Zs. Tóth.

${ }^{11}$ То́тн 2008, 9.

${ }^{12}$ TÓтH 2008, 9. According to the opinion of the excavating archaeologist, made in Severan Age. Tóth 2008, 9.

${ }^{13}$ This conception is confirmed by the in situ remains of wall-painting, that continue on the Eastern wall as well. See excavation photos and Fig. 1, too.
${ }^{14}$ The building of the wall-painted room, and it broader excavated area (Kossuth Square) was frequently disturbed with the wooden structure buildings, ovens of Late-Roman times, and burials from the end of late Roman Age, furthermore, it was extensively disturbed by the pits and wells of the Middle Age occupation period. То́тн 2008, 10-19.

${ }^{15}$ The western part of the building was destroyed at the time of the construction of the public convenience built here. Based on the kind information of Zs. Tóth. 


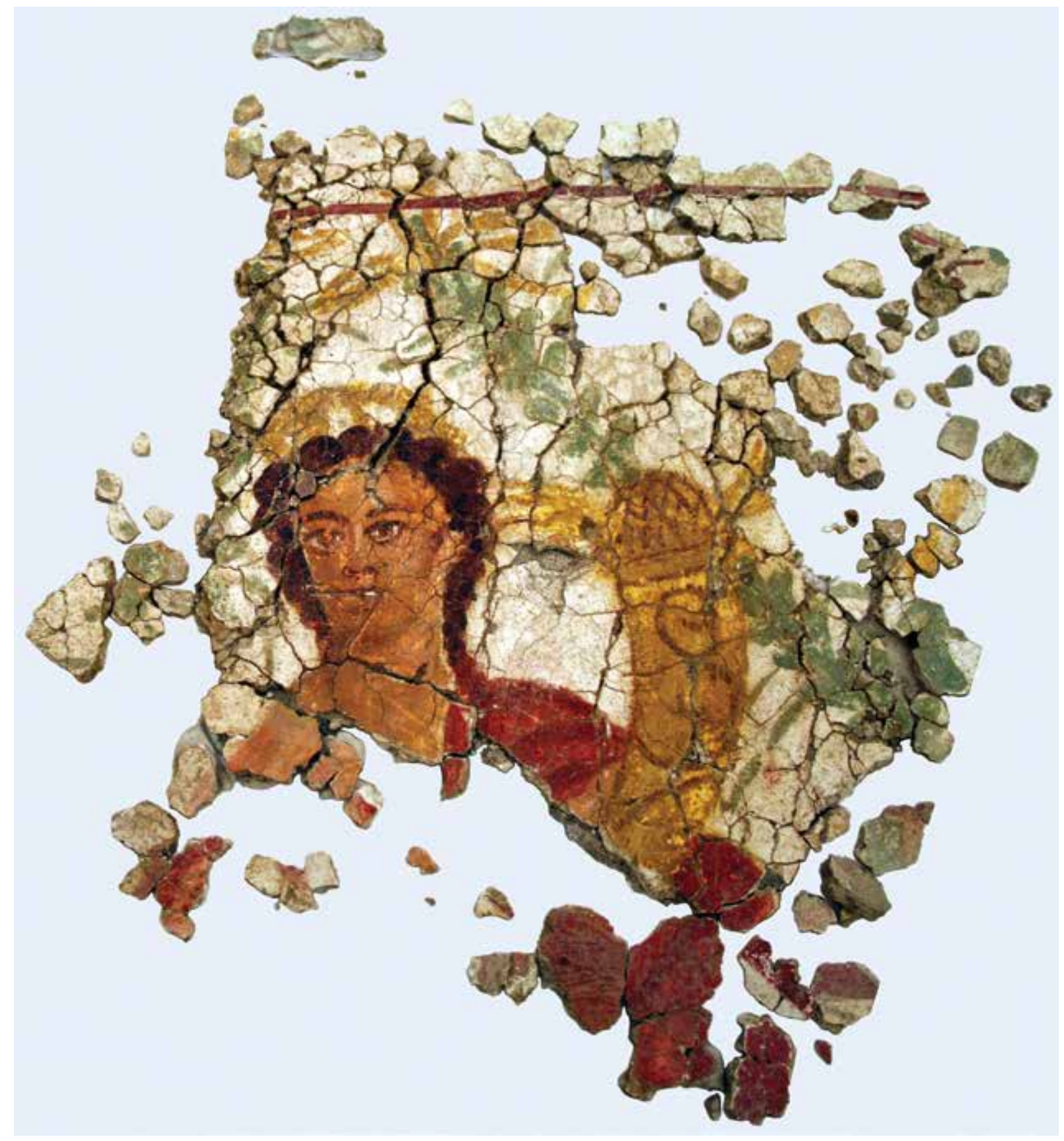

Fig. 2. Fragments of the genius wall-painting after being picked up before framing (photo: Zsolt Tóth) 

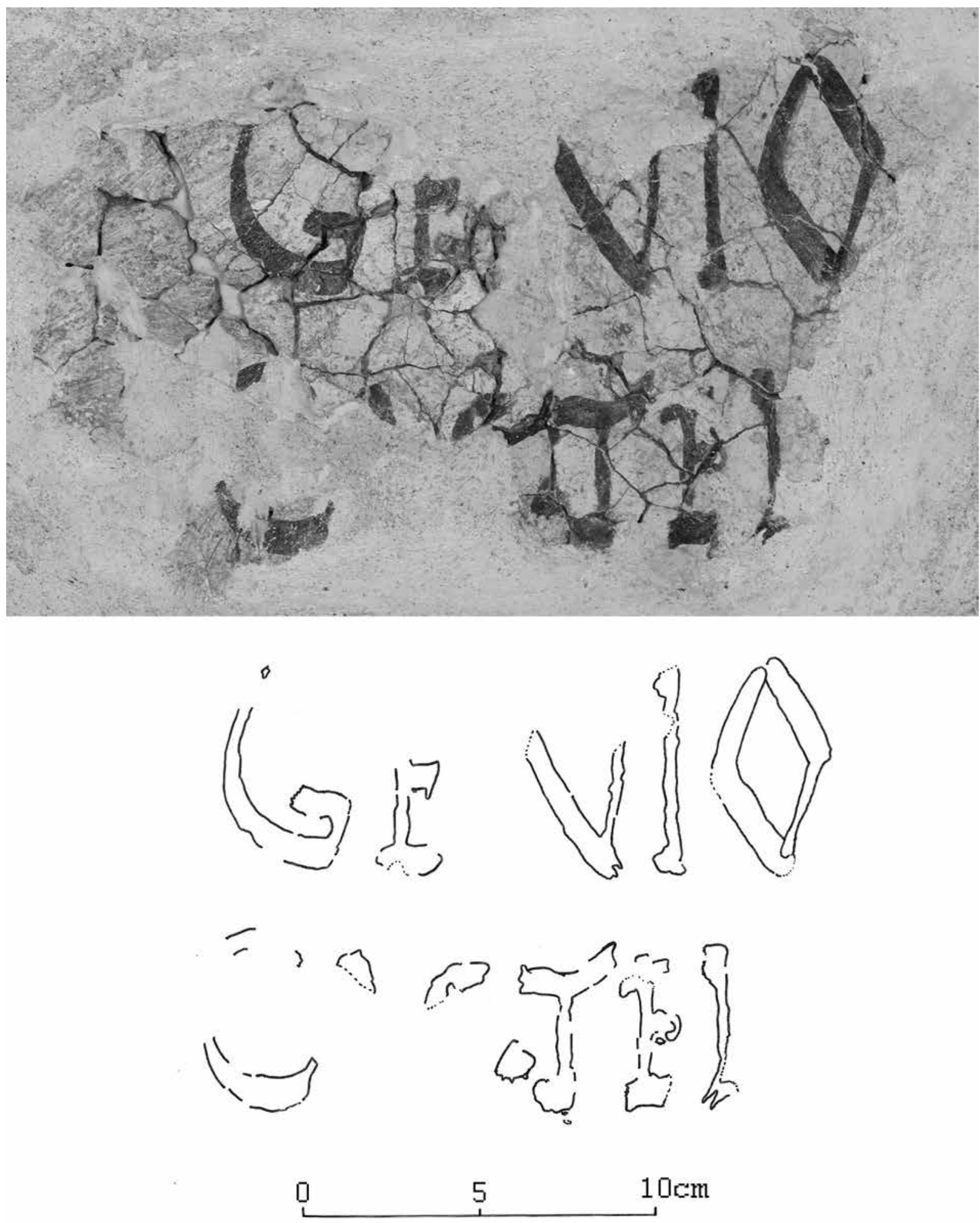

Fig. 3. Painted inscription recovered along with the wall-painting after assembly and restoration, together with the drawing of the inscription 


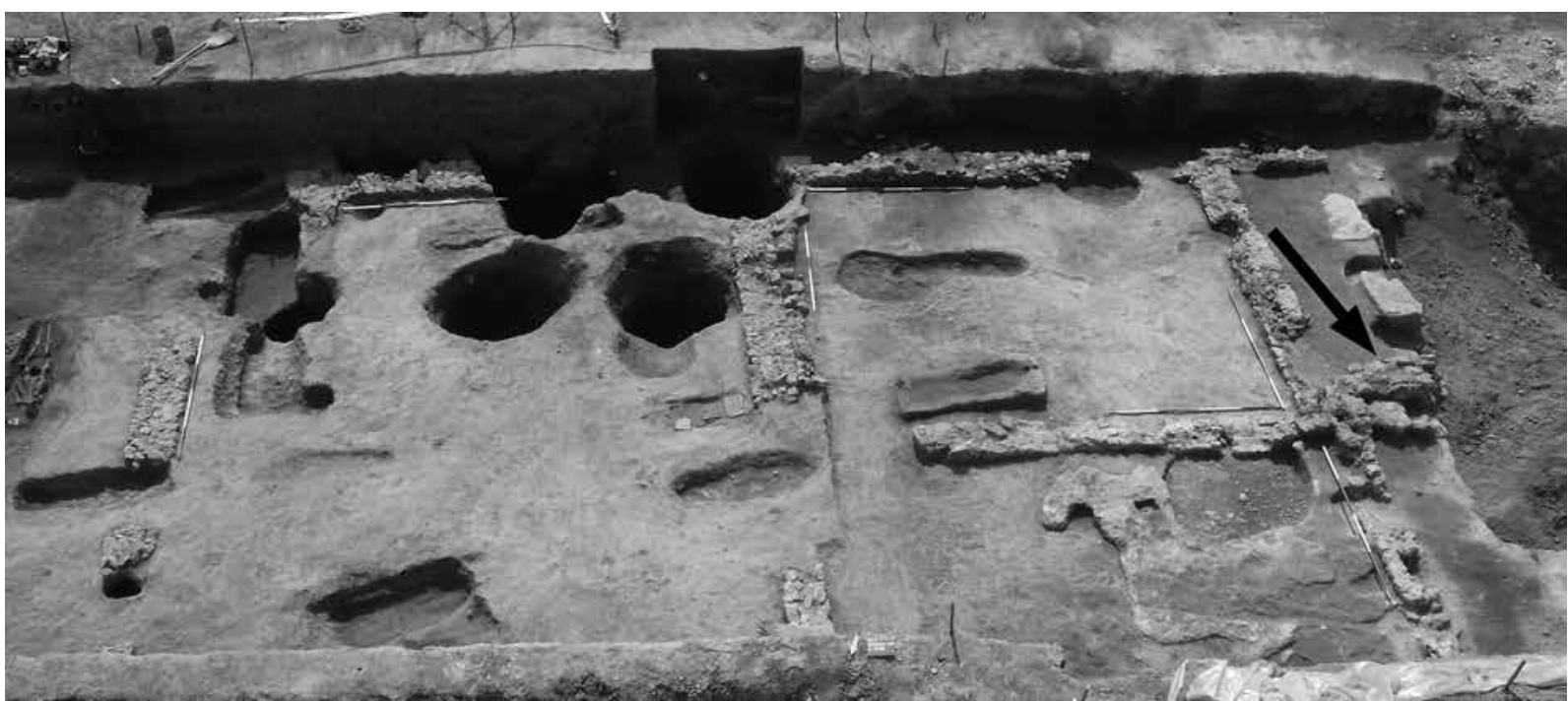

Fig. 4. The building complex recovered on Kossuth Square with the site of the wall-painting (see arrow), excavation image from the north (photo: Zsolt Tóth)

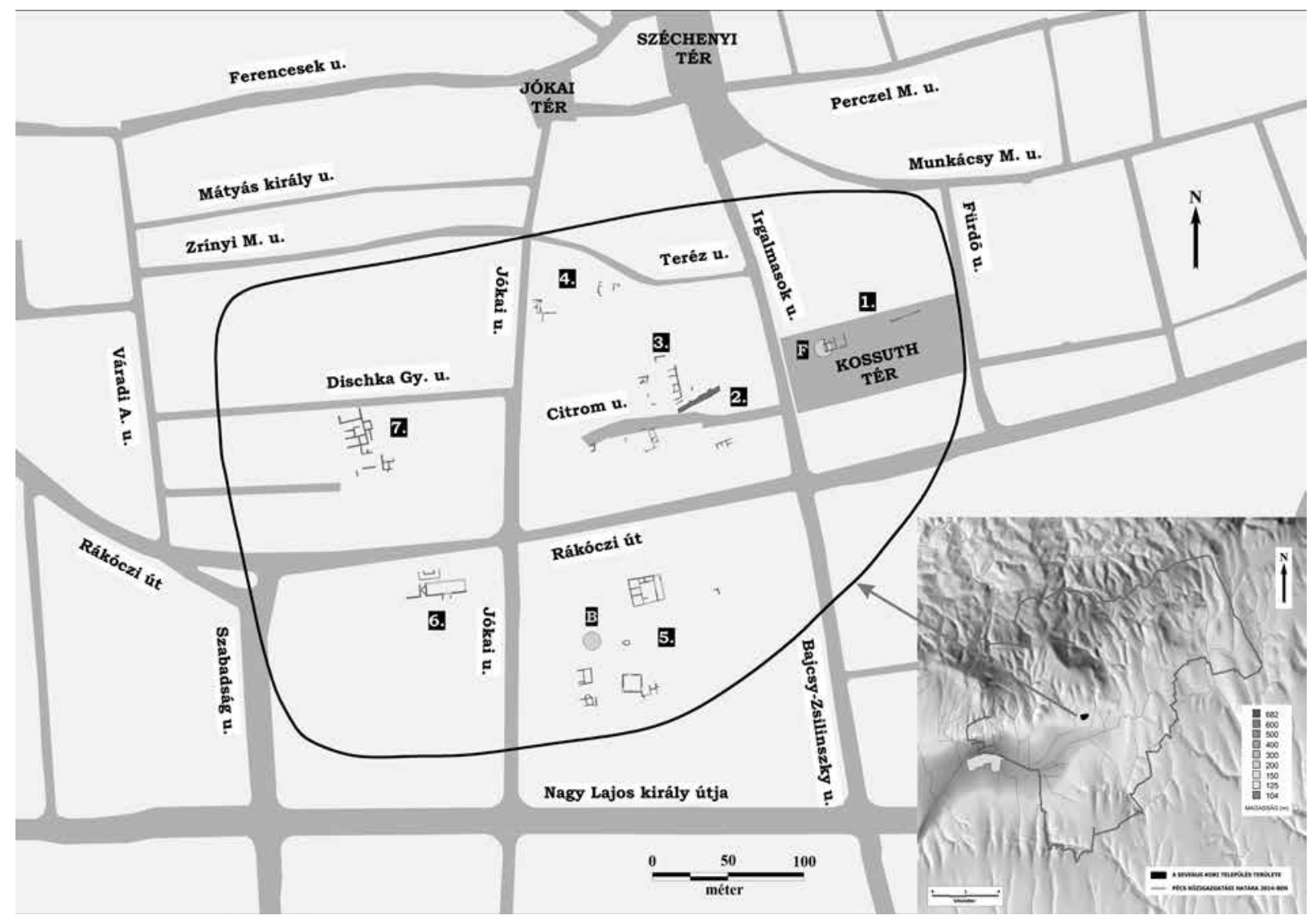

Fig. 5. Severan Age period of Sopianae with known building remains on today's street map:

1: Kossuth Square; 2-3: Citrom Street; 17-19 Jókai Street; 4: 11-13 Jókai Street; 5: Sopianae Square and House of Traders; 6: Rákóczi RoadJókai Street SW corner; 7: West of the Postpalace; F: The location of the wall-painting of the genius; B: The Beneficiary's Sanctuary. Small map: The location of the Roman settlement (black) in the present administrative area of Pécs (Compiled by Zsolt Tóth) 
During the excavations aligned perpendicular to the northern wall decorated with the figural scene, two rectangular stone bases carved of one piece could be observed ${ }^{16}$ possibly statue-bases. Besides, a fragmented, thoroughly detailed stone carving of an eagle with outstreched wings came to light from the area of the same room, from the destruction layer of the building. ${ }^{17}$ (Fig. 6)

\section{SOPIANAE IN THE $3^{\text {RD }}$ CENTURY AD AND THE BUILDING OF KOSSUTH SQUARE}

Sopianae was founded in the crossing of important traffic routes. ${ }^{18}$ At the end of $2^{\text {nd }}-$ beginning of $3^{\text {rd }}$ century during the reconstructions ${ }^{19}$ following the Marcomannic wars, ${ }^{20}$ stone buildings, heated building complexes, paved roads were built. ${ }^{21}$ (Fig. 5) The wall-painted building discussed in this paper is situated in the Eastern part of the $500 \times 300 \mathrm{~m}$ settlement, ${ }^{22}$ close about from to its borders defined by excavations so far, 80 meters to the North ${ }^{23}$ from the East-West main road. ${ }^{24}$ Further away, about 250 meters South-West in the Southern part of the settlement, a beneficiarius shrine erected in the first half of the $3^{\text {rd }}$ century was recovered. ${ }^{25}$ According to contemporary building remains, ${ }^{26}$ the East-West main road recovered on Citrom Street and building parts renewed several times ${ }^{27}$ can be connected to the Kossuth Square building complex.

Following the Sarmatian-Roxolan break-in in $260 \mathrm{AD}$, the inhabited part of the settlement narrowed, some of the earlier buildings were refurbished and futher used. ${ }^{28}$ Others, like the wall-painted building complex in Kossuth Square were given up in this period..$^{29}$ Later, at the end of the $3^{\text {rd }}$ century AD, Sopianae became the political and administrative centre of the newly established Valeria province. ${ }^{30}$ In one of the domestic villas neighbouring the settlement representative, figural mosaic floors of high artistic value were recovered. ${ }^{31}$

\section{DESCRIPTION OF THE WALL-PAINTING}

In the centre of the composition, probably in the centre of the side wall ${ }^{32}$ a perhaps full-length depiction of a young male figure, genius is situated, that of only fragments up to chest-high were recovered. ${ }^{33}$ (Figs 2, 7) The

${ }^{16}$ Based on the kind info of leading archaeologist.

${ }^{17}$ То́тн 2008, 9. Excavation archaeologist thougt it was a decoration of the building. Sizes: width: $30 \mathrm{~cm}$, remaining height: $37.5 \mathrm{~cm}$, depth: $13 \mathrm{~cm}$. JPM accession no: 2.1 .2015 . The head of the eagle is missing, it was a free standing stauette, made for one perspective. A detailed description of stone eagle see below in the appendixpaper by B. Fabián and Á. Szabó.

${ }^{18}$ PozsÁrkó 2004, 271; KovaliczKY-Tóth 2014, 81; KovALICZKY-TóTH 2016, 20.

${ }^{19}$ No relating data concerning municipal standing were found from this period. The name of the settlement is known from Itinerarium Antonini Augusti et Hierosolymitanum 231.9, 232.8, 264.1, 264.7, 267.5 Berlin 1848, and from Ammianus Marcellinus (AmmMarc XXVIII. 1. 5.) Ammianus Marcellinus: History. Loeb Classical Library. London 1986. KоvaLiCZKY-Tóth 2014, 81; KovALICZKY-TóTH 2016, 21, 24.

${ }^{20}$ About Marcommanic wars recently: KovÁcs 2014, 113174. About local devastation of Marcomannic wars: FÜLEP 1984, 33, 272-273; MócsY-FITZ 1990, 38-39; FARKAS-KÖHEGYI 2002, 71-78, KovALICZKY-TóTH 2016, 22.

${ }^{21}$ Buildings on stone bases, or with stone upper walls characterized this period. KovALICZKY-TÓTH 2014, 82; KOVALICZKY-TóTH 2016, 24.

${ }^{22}$ In the area bounded by Rákóczi Road-Jókai Str--Nagy Lajos Király Road- Bajcsy-Zsilinszky Str. there were surely stone buildings standing in Severan Age. KovALICZKY-TóTH 2016, 25.

${ }^{23}$ See map: KovaliczKy-Tóth 2014, 83, Fig. 4; KovALICZKY-TóTH 2016, 24.
24 Today's Rakóczi Road.

${ }^{25}$ POZSÁRKÓ 1990, 109-118; KÁRPÁTI 2004, 281-282; VISY 2013, 121-123; Kovaliczy 2015, 76; KovalicZKY-TótH 2016, 25.

${ }^{26}$ See summary of building contemporary to the wallpainting on the map attached to the article. (Fig. 5)

${ }^{27}$ KÁRPÁti 2004, 282-285; Visy 2013, 117-119, Fig. 22.

${ }^{28}$ E.g at buildings recovered on Sophianae Square (period 3): KovAlicZKY 2015, 85; KovALICZKY-TóTH 2016, 26.

${ }^{29}$ То́тн 2008, 9-10 and the kind verbal statement of excavating archeologist; KovALICZKY-TóTH 2014, 83.

${ }^{30}$ Based on circumstantial evidences: AmmMarc XXVIII, 1 , 5. Considering the seat of the praeses opinions differ amongst researchers: AlFöldi 1942, 699; NAGY 1973, 107; Mócsy 1962, 611; FITZ 1976, 387; FITZ 1993-1995, 1180-1181, 1175-1183; Tóтн 2006, 60-64 KovALICZKY-TóTH 2016, 27; summarized lately in: VISY 2013, 136.

${ }^{31}$ E.g. the figural mosaic of the villa of Nagyharsány: Mráv 2015, 53, Fig. 155.

${ }^{32}$ In painted scenes the figure of genius is usually located in the middle of the composition. REINACH 1922, 103ff., pic. 1,3,5,6. The two decorating wreaths starting on both sides of the head also suggest the centered positioning of the figure. Similarly two wreaths are to be observed on: FröHLICH 1991, Kat. L 91, Taf. 1; Kat. L 8, Taf. 2; Casa delle Pareti Rosse: Kat L 96, Taf. 8.

${ }^{33}$ Apart from the reconstructed wall-painting, some fragments were recovered, painted red, supposedly a parts of an attire. Concerning this, we can suppose, that our figure was the part of a larger, full body depiction, not a bust only. 


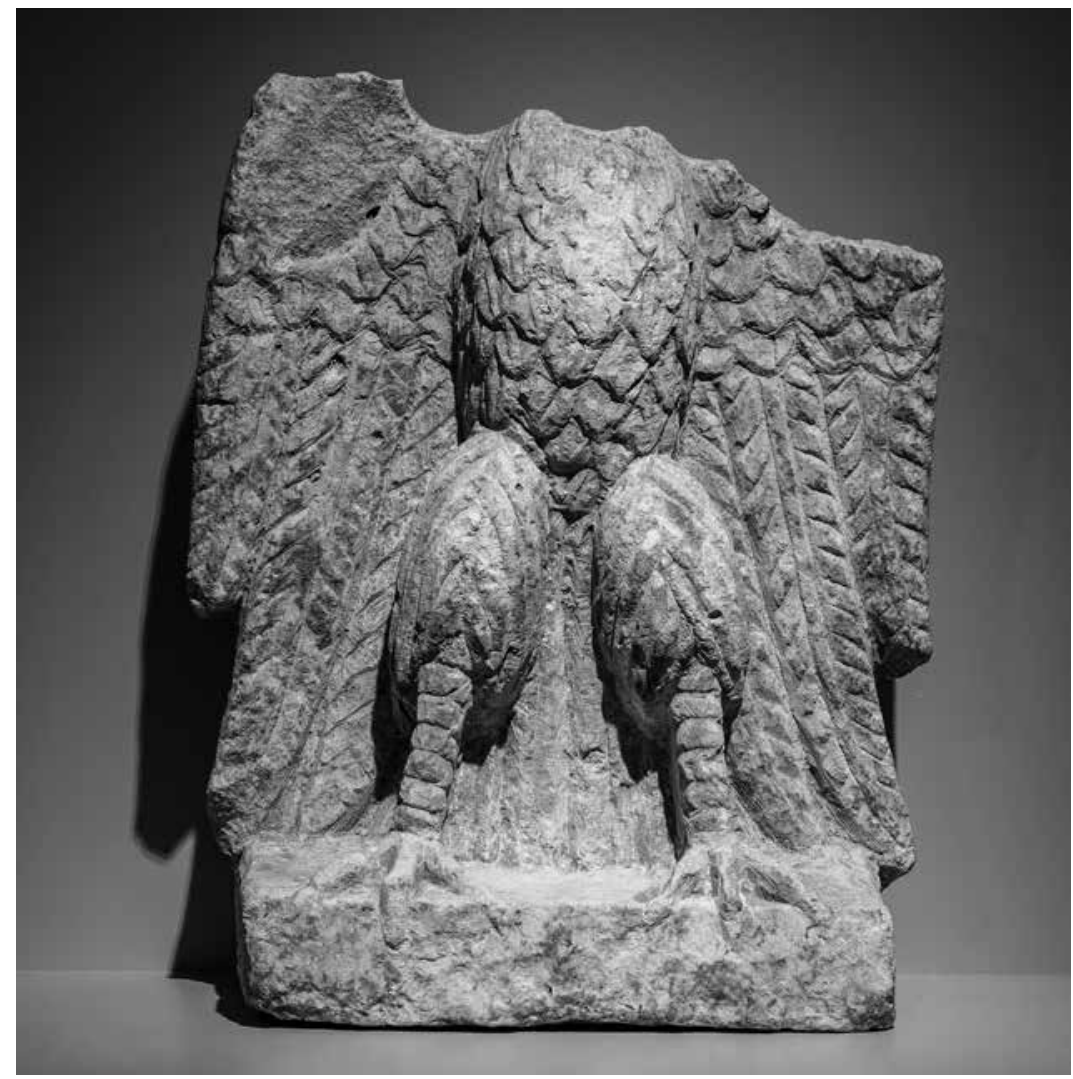

Fig. 6. The fragmentary statuette of an eagle from the destruction layer of the Severan-era building (photo: Zsolt Tóth)

wall-painting is of red, green and yellow colours and their shades on a white background. (Fig. 8) Genius is wearing a yellow, semicircular crown. (Fig. 8) Four-five splits appear on the crown, along with a larger proturberance ${ }^{34}$ on the upper arch at one point. The hair of the figure is reddish brown, wavy or curly, and is down to his shoulder, to the hem of his dress. The curliness and the light and dark effects of the hair are enhanced with loops and helices and emphasized with black or very dark brown lines, or with shorter loops on the left side of the head, and with a dark line contouring the right side of the face. Out of the frizzly hair, regularly spaced, really short curls hang in the face.

The figure turns his head and his upper body slightly to the right. (Figs 2,8) The colours of the body are marked with a thick layer of orangeish or light brownish colour. Above this, eye-brows,${ }^{35}$ eyes, ${ }^{36}$ the nose,${ }^{37}$ and the mouth $^{38}$ were created applying more colours on one another, ${ }^{39}$ thoroughly detailed, precisely taken care of the light and shade effect. The left cheek is visible more, its lighting is also inflicted with putting various shades next to each other. ${ }^{40}$ There is a smaller pink spot above the left eyebrow that also reflects to lighting. The left ear is not covered with hair, but no emphasis was put on its lifelike look by the artist. At the height of the nostrils, in the central point of the face there is a small mark, which probably helped the designation of the position of the eyes and of the face on the mortar layer. The lower boundary of the face and the chins were marked with reddish brown and lighter brown colours.

${ }^{34}$ A smaller proturberances can be observed by the splits rising from the upper plain of the headdress which results in the use of brushes. There is only one significant bump that may be a result of innaccurate gathering of the fragments. However, painting direction of the base is right (!).

${ }^{35}$ With red-reddish brown colours.

${ }^{36}$ Grains were painted applying five colours above one another.

\footnotetext{
${ }^{37}$ Reddish brown, dark pink, light pink colours were used
}

${ }^{38}$ The mouth was created using reddish brown and two different shades of pink.

${ }^{39}$ Eyes, nose, mouth and eyebrows were modelled with red, then red-brown above it, followed by darker pink, lighter pink and finally white.

${ }^{40}$ Going from the nose towards the ears painting on the left face is characterized with a vertical painting method applying light pink, later dark pink colours. 


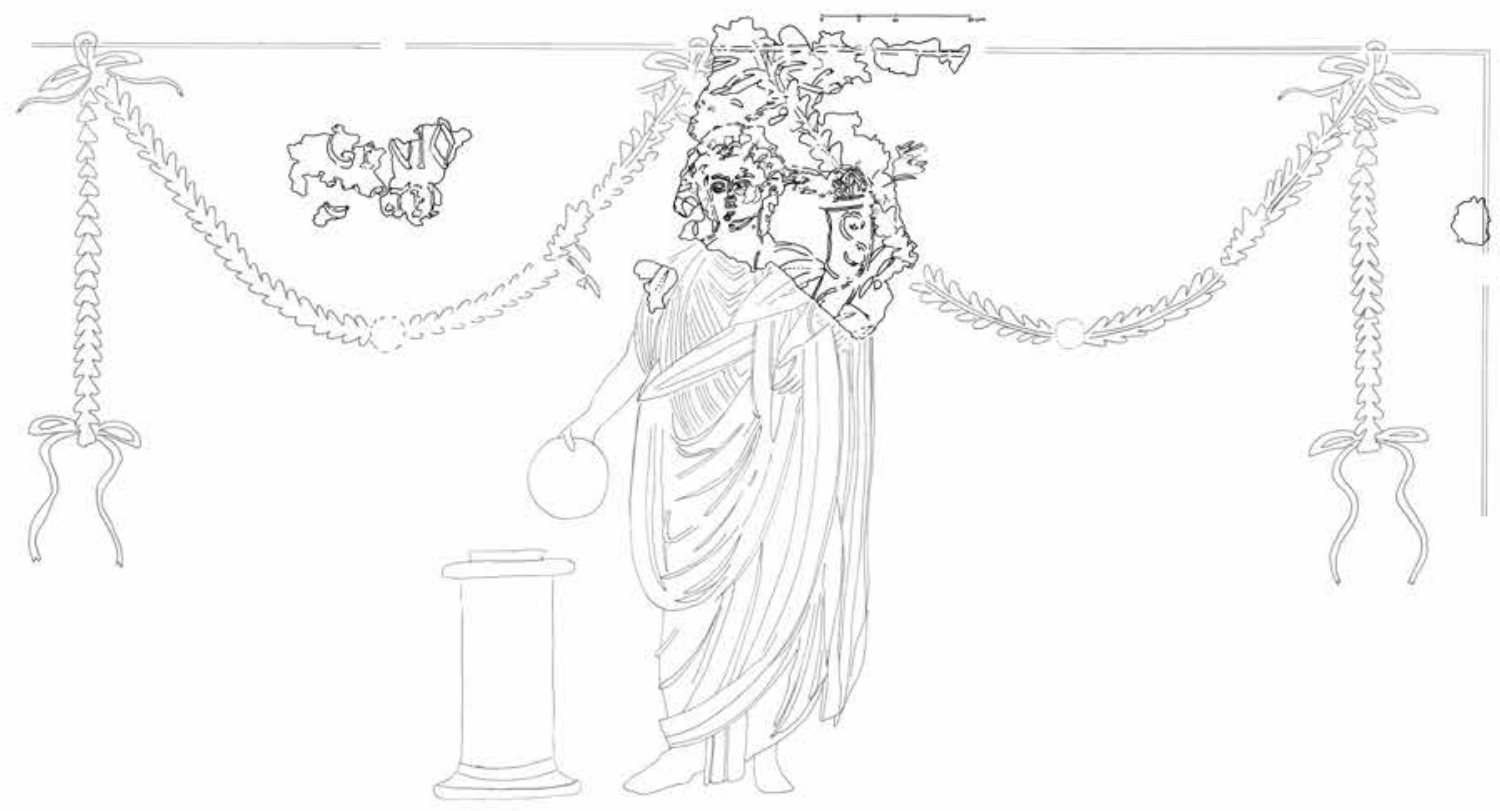

Fig. 7. A possible reconstruction of the wall-painting (Anita Kirchhof)

On the left shoulder of the figure parts of a densely plaited red attire, maybe a toga or a cloak or a shawl (pallium) can be observed. ${ }^{41}$ Red areas were created with multiple layers of paint, thick plaits of the dress were marked with darker and lighter red stripes, sometimes turning purplish or rather brownish-reddish. On the right side of the figure, clearly above the shoulder a light reddish stripe runs. ${ }^{42}$ (Fig. 9) This suggests that the figure is wearing an attire covering his whole body, maybe a $\operatorname{tog} a^{43}$ (or toga purpurea) and a reddish tunica underneath. On the left side of the figure, right by the hem of the garment, a thin white stripe left unpainted can be observed. ${ }^{44}$ (Fig. 8) This unpainted stripe runs in the line where the face meets the hair, so its likely that it can be interpreted as a previously marked boundary, a designation of the hem of the cloth.

The figure is holding a cornucopia in his hand. Some of his bare arm is visible next to it. ${ }^{45}$ (Fig. 10) The cornucopia is emphasized by a reddish brown colour on a yellow basis. Reddish brown colour highlights the contour and the ' $\mathrm{S}$ ' shaped or simple twisting tendril like decorative motif ${ }^{46}$ running on the outside. The upper broadening part, the rim of the cornucopia is marked with a double, horizontaly encircling redish brown line. There is a semi-

${ }^{41}$ Because of the fragmentation of the depiction, it is not possible to determine the exact attire of the figure. Both versions are possible. Hereby I would like to thank Judit Pásztókai Szeőke for sharing her opinion with me.

${ }^{42}$ By assembling, the two body coloured fragments were placed to the right side of the figure to the shoulders. Their insertion to the larger wall-painting isle is not unequivocal. See photos taken during restoration.

${ }^{43}$ Genius was usually depicted wearing a complete toga, or their upper body left uncovered. OTTO 1910, 1164; KUNCKEL 1974, Taf. 1-96.

${ }^{44}$ The width of the stripe left white is $2-4 \mathrm{~mm}$. In this case it is not a white stripe painted over the previous paint layers, but the area was left unpainted and the white colour of the base is visible. was used here.

${ }^{45}$ The orangeish body colour used on the face and the neck

${ }^{46}$ Twisting decorating motifs, voluta like decorations, acanthus, amber or vine motifs were very popular in Roman art amongst others of building decorations, wall-paitings, mosaics, stucco decorations, etc. SchmidT-Colinet-PlatTNER 2004, 84-85, Fig. 121. Found on the following: Aquincum, wall painting of Tavasz Street: SzIRMAI 1984, 253, Figs 5-6; wall-painting of the building complex of Búvár-folyamőr Street: PARRAGI 1991, 204, Abb. 3; on the stucco imitation of the wall-painting of Szőlőkert Street: ZsIDI 2000, 151, Fig. 14; framing the mosaic of apsis of room 7 of Villa of Hercule, beginning of $3^{\text {rd }}$ century AD: Wellner 1969, 263, Fig. 29, North African mosaics e.g from Sousse: FRADIER 1976, 78; Late Roman period $\left(3^{\text {rd }}-4^{\text {th }}\right.$ century) mosaic of Villa of Casale room 33 (Xystus) acanthus decorated with busts of animals: CATULLO 2000, 66-67; Savaria, mosaic of late Roman proconsul's palace: KISs 1973, Pl. XIV$\mathrm{XV}$, etc. Altough the upcoming examples can be dated to an earlier period than the wall painting discussed, they illustrate the use of this decorating motif on different materials: Ara Pacis Augustae: RAMAGE 1999, 104, Abb. 3.28; silver cup outer decoration: RAMAGE 1999, 104, Abb. 3.29; wall-painting of Bolsena from 30 AD: BARBET 2009, 165. 


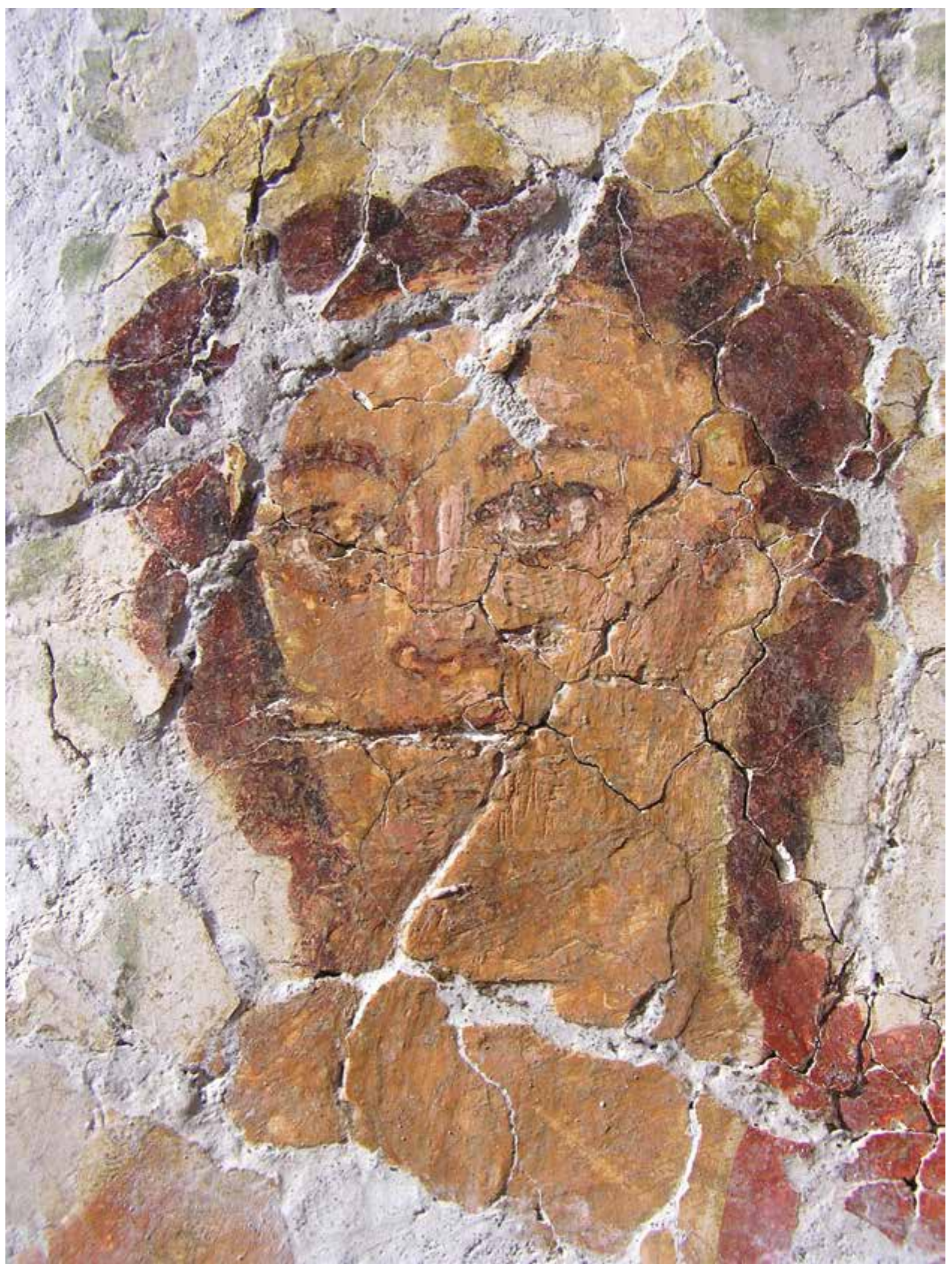

Fig. 8. The portrait of genius depicted on the wall-painting close up 


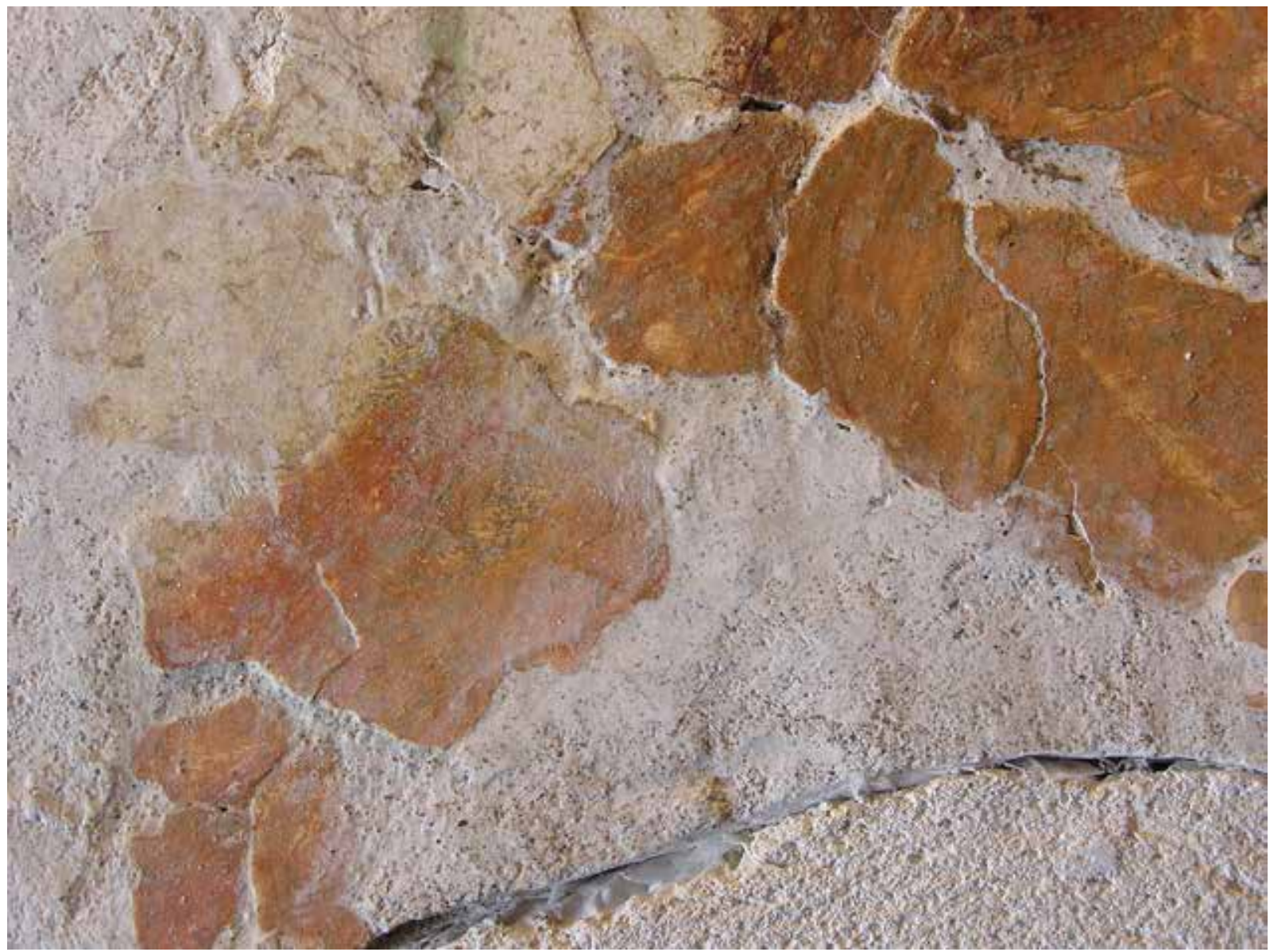

Fig. 9. A fragment of the figure of genius with a detail of a red attire

circular shape, perhaps a pinecone depicted in the cornucopia. The contour and the flakes of the pinecone were also rendered with a reddish brown ${ }^{47}$ colour, perpendicular hatches, repeating pattern of rhombuses.

From the point where the cornucopia meets the pinecone yellow grainspikes bend in two directions, once filling in the area between the head of the figure and the cornucopia and also leaning in the opposite direction.

The background of the grainspike is painted light yellow with a patchlike technic. Above that grains ${ }^{48}$ are depicted with using darker or more paint. Above that, using a reddish brown colour, ${ }^{49}$ shades were drawn, creating a life-like image.

Beside all the above, the other shoulder and the launch of the right arm of genius is visible on the wallpainting isle recovered. The whole hight of the figure, based the remaining fragments and the proportions of the body can be composed to a little less than $90 \mathrm{~cm},{ }^{50}$ about half a man size. (Fig. 7) The thin red line running by the head of the figure marks the border of the picture. The complete hight of the picture from the red line to the bottom of the figure, the floorline, ${ }^{51}$ or maybe a little lower was about $100-120 \mathrm{~cm}$. The footing and the upper zone above the red line adds up to these dimensions. ${ }^{52}$

${ }^{47}$ Thickness: $2 \mathrm{~mm}$.

${ }^{48}$ Number of grains identified: $3-4$ pieces.

${ }^{49}$ In order to emphasize the effects of light and shadow, 1.5-2-3 mm wide stripes were applied and even $5 \mathrm{~mm}$ thick leafs were painted there.

${ }^{50} 88.8 \mathrm{~cm}$

${ }^{51}$ Presumably the bottom (horizontal) border of the picture was situated at his foot, also serving as the footline of the composition.
Similarly, the frame of the image field is the same as the soil foodline in several wall-paintings of Zeugma: BARBET 2005, Pl. XXV,1,5, Pl. XXVI,3.

${ }^{52}$ From the red strip upwards, the white solid colour of the wall surface continues traceably on the preserved fragments. The inscription, accoring to one of the ideas, might have been in this upper zone, above the figure. 


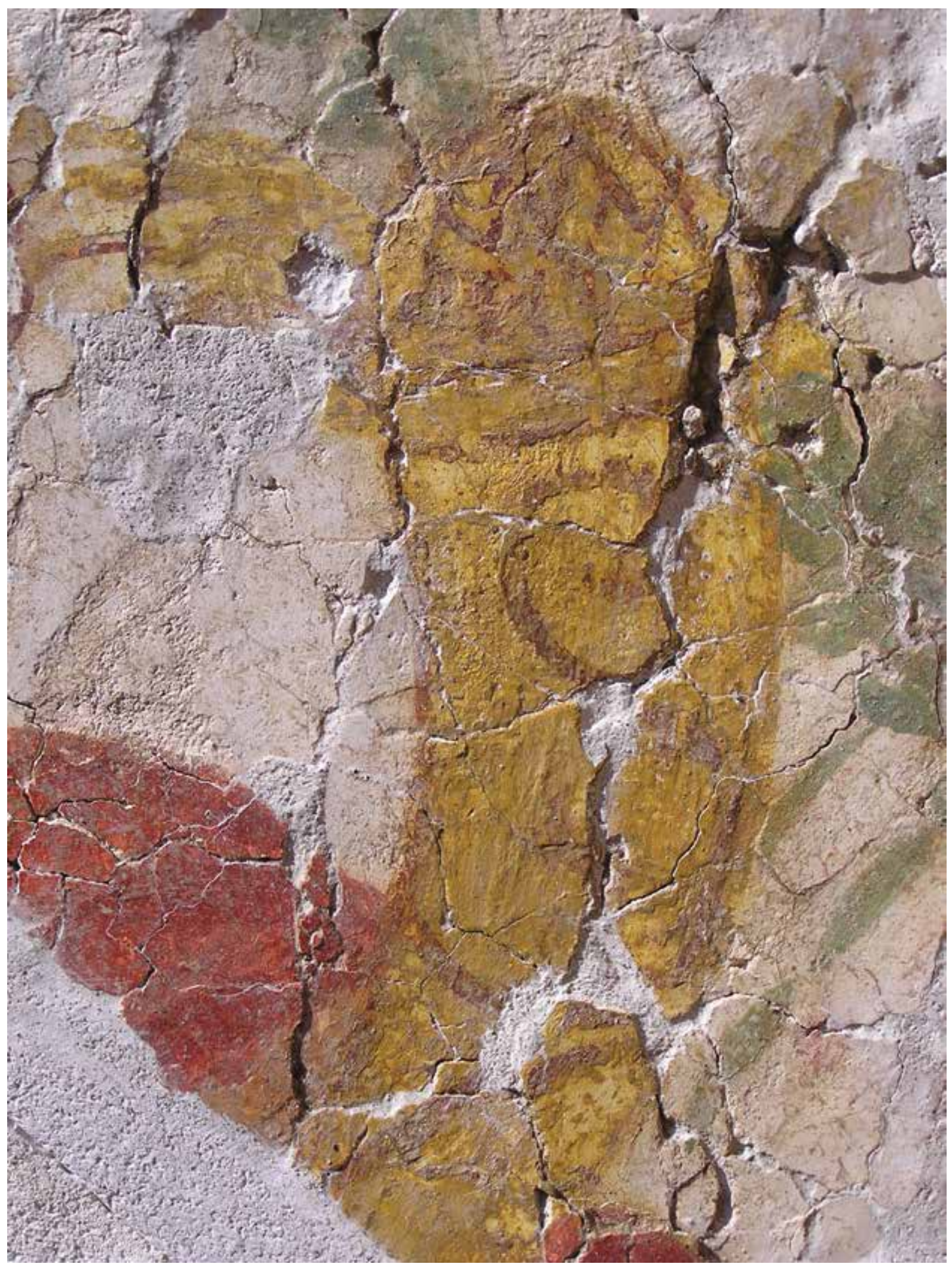

Fig. 10. Depiction of cornucopia from close up with a twisting tindrel motif, pinecone and grainspike 
Unequivocal identification of the figure as genius became possible after assembling the inscribed pieces found neighbouring the figural fragments. ${ }^{53}$ The text is arranged in two lines. The word GENIO is clearly readable of the 6-6.1 cm size letters of the upper line, despite its fragmentation. (Fig. 3) Beneath, slightly smaller, approx. $4.7 \mathrm{~cm}$ tall letters, $C V T E L$, are recognizable. ${ }^{54}$ The text in the lower line being very fragmented is uncertain to interpret. The inscription, just as the dominant shade of the figure is reddish brown. A green spot, part of a leave at the end of the upper line of the painted inscription suggests that the inscription was probably situated in the center of the area next to the figure, at about eye level. ${ }^{55}$ (Fig. 7) Though the possibility that it was located above the red line that frames the composition, in the upper zone above the figure can not be excluded. ${ }^{56}$

On both sides of the figure, a garland made of green, monochrome leaves rises steeply upwards. ${ }^{57}$ The one on genius' left side is more intact. The garland does not cover the figural image, it is depicted in the background breaking its continuous line at the cornucopia. At the bottom of the cornucopia, to be exact at the point where the wreath and the cornucopia meets, a dot can be observed that probably was to designate the design. The part of the garland above the cornucopia runs in an almost straight line towards the framing red stripe. Its leaves are opened out- and upwards, bending curved on both sides. (Fig. 2) On those parts of the garland where there were no other depictions, some longer, wider overhanging leaves are not connected directly to the stalk. They were intended to fill the white background space inbetween the patterns. ${ }^{58}$ At one point there is even a red $\operatorname{dot}^{59}$ in between the strongly overhanging leaves, indicating a flower pinned there for decoration. It was not intended to present the light and shade effect on the garland neither with using different colours nor with using different shades of one colour. There is a minimal difference between the colour of the leaves facing the figure and the colour of the stalk being slightly darker. The garlands are tied up to the red line ${ }^{60}$ framing the composition with a yellow ribbon, that's bow ${ }^{61}$ is clearly visible. (Fig. 11) The section of the ribbon tossed over the red line curves above the red line. Out of the garland streching on the right side of the figure only some parts of the yellow bow and parts of the green leaves are visible. The distance between the launches of the two garland must have been approx. $9 \mathrm{~cm}$. At last, another motif is clearly visible, the simple, thin, red line marking the boundaries of the central zone.

\section{THE MORTAR, AND THE PROCESS OF PAINTING}

The figurative scene becoming detached from the wall fell intact to one place presumably when the upper adobe wall collapsed. ${ }^{62}$ The mortar base of the wall-painting is relatively $\operatorname{thin}^{63}$ because of this and the compounds of the mortar, the wall-painting became very fragmented. Both Plinius ${ }^{64}$ and Vitruvius ${ }^{65}$ suggested a thicker mortar consisting of several layers for the base of wall-paintings. Apart from a few exceptions ${ }^{66}$ it is generally true concerning Roman and thus Pannonian ${ }^{67}$ mortar of wall-paintings that threefold structure (three layers of mortar) is used. ${ }^{68}$ This can be observed on the discussed wall-painting fragments as well. ${ }^{69}$ (Fig. 12) The back of the mortar examined

${ }^{53}$ Figural and inscribed fragments obviously belong to the same painting, based upon their style of painting, colours applied, their mortar base (the layers of the inscribed fragments are not examinable at the moment due of being inserted) and their finding conditions.

${ }^{54}$ The text is arranged in two lines. An interpretation of the inscription see below in the appendix-paper by B. Fabián and Á. Szabó.

${ }^{55}$ In the upper line of the text, next to letter $O$ of the word GENIO a piece of a green leave of the garland can be seen. It's probably the detail of a leave reaching down from the garland to the inscription. Presumably leaves were sorrounding the inscription to fill out the space.

${ }^{56}$ According to the photos taken during the excavation, fragments of letters were mostly unearthed North of the figure, close to the wall, orsomewhat East of it. This theory is supported by the practice of putting names of mythological figures depicted on wallpaitings neighbouring the figure, most often above or by the head. eg. from Brigetio, Pannonia: Bíró 2001, 9-12, 22.

${ }^{57}$ The average size of the leaves is $2.5 \times 1.2 \mathrm{~cm}$.

${ }^{58}$ Usually one to three leaves per side on both sides.

${ }^{59}$ Dimensions: $1 \times 1 \mathrm{~cm}$.
${ }^{60}$ Width of the red stripe: $6 \mathrm{~mm}$.

${ }^{61}$ Size of the bow: $6.7 \mathrm{~cm}$.

${ }^{62}$ According to the excavation observations the wall-painting fragments were found amongst clay layers. Verbal statement of Zs. Tóth.

${ }^{63} 1-1.5-1.8 \mathrm{cms}$ thick.

${ }^{64}$ Plin, Nat. hist. XXXVI. 55, 176.

${ }^{65}$ Vitr, De arch. VII. 3. 6.

${ }^{66}$ Multiple layered mortar is observable amongst wall-paintings contemporary to Vitruvius. eg. in Livia's House, Villa Farnesina, and in Pompeii amongst wall-painting Styles I and II. LING 1991, 199.

${ }^{67} \mathrm{Eg}$. concerning the first painting period of the wallpainting of Aquincum and Baláca, the wall-painting of yellow-purple-, and red dining room: КIRCHHOF 2011, 48, 153, 567, 654.

${ }^{68}$ LING 1991, 199.

${ }^{69}$ Only the fragments not inserted were available for examination. Upper intonaco layer: $2 \mathrm{~mm}$ thick and of white colour; arriccio 2 layer: $4 \mathrm{~mm}$ thick, mixed with organic materials, sand and pieces of lime; at last arriccio 1, bottom layer is a 8-9 $\mathrm{mm}$ thick, more crumbly layer containing more sand mixed with larger pieces of lime, no larger stone fragments added to it are observable. 


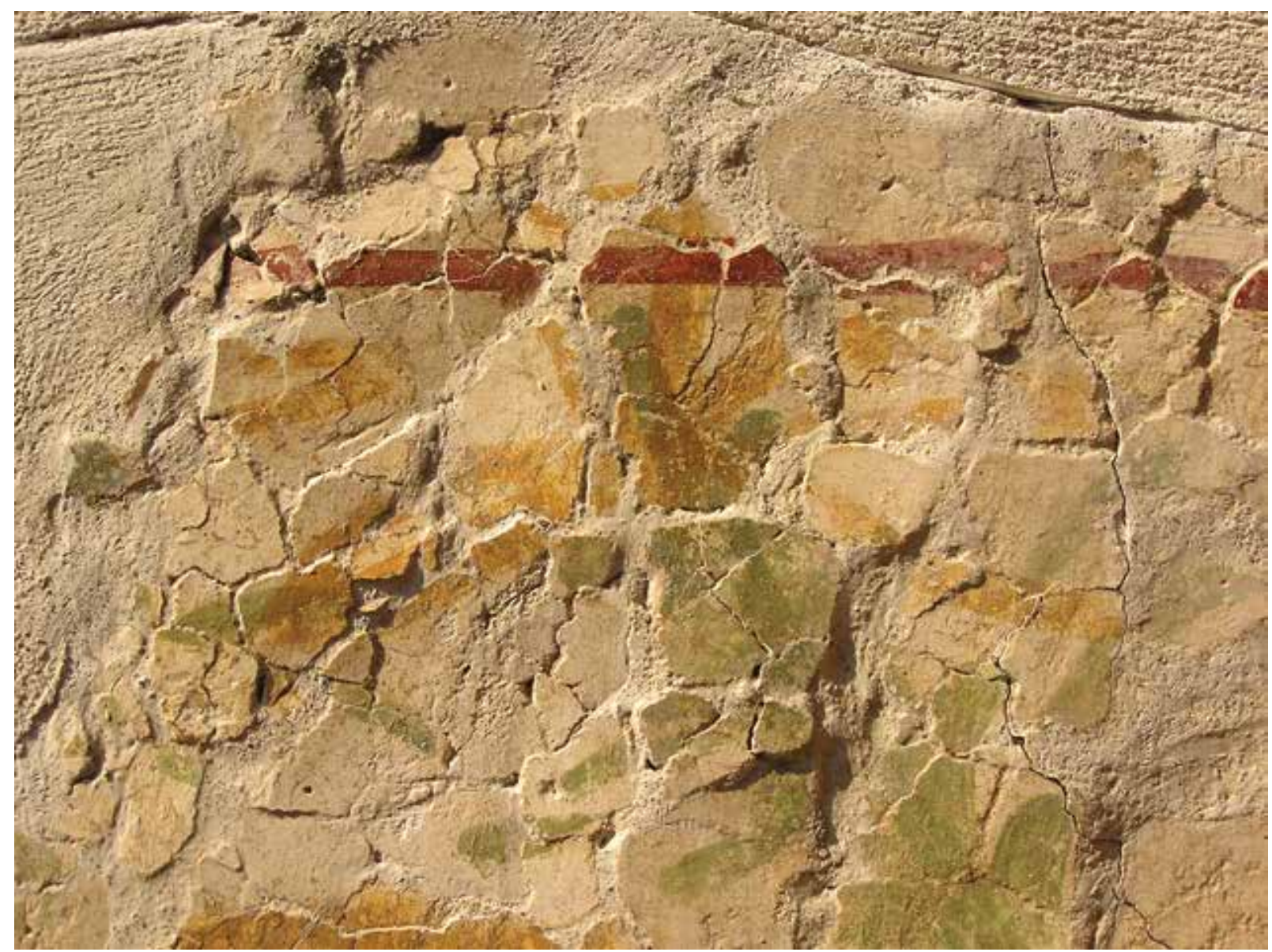

Fig. 11. Depiction of the bow of the ribbon that ties up the green garland

is smooth (Fig. 13), slightly convex, no imprints or traces of clay are found on them. ${ }^{70}$ The thinness of the mortar layer, and the realative smoothness ${ }^{71}$ of the back of the fragments could refer to the wall-painting being a renewal or an overpainting of a previous one, however, this is contradicted by the fact, that during the excavation no evidence referring to an earlier wall-paiting came to light, no fragments with wedged interior surfaces ${ }^{72}$ or intact wall-painting pieces with two paintings above each other came to light. There were no positive imprinted signs of wedging either on the back side of the fragments.

The wall-painting's last layer of mortar, the so called smooth plaster (intonaco) is white and its average width is $2 \mathrm{~mm}$. The background of the painting is uneven, the orientation of the base painting and the marks of the

${ }^{70}$ Between the footing built of stone and the first preparation plaster layer of the wall-painting there supposed to be a thin layer of argile pugged onto the wall. On the excavation photos the wallpainting preserved in situ on the footing came loose from the wall, which means it was not directly applied to the stone wall. One can assume there was an intermediated clay layer (approx. 1-2 cm thick) which continued over the upper part of the wall made of adobe. I could observe a similar clay layer at the latest excavations in the so-called Painter's House in the Civil Town of Aquincum (LÁNG 2012), and in the case of the wall-paintings found in the Military Town of Aquincum at the excavations of Budapest III, Hunor Str. 24-26, in the case of the wall-paintings preserved in situ. КIRCHHOF 2014, 126.

${ }^{71}$ The fragments do not have a stright back which would be typical of the renewals or renovations. In the photos taken at the excavations, the back of the larger painting islet appears to be smooth and there is not a trace of an earlier wall painting's positive traces. Because of this it is likely probable that the painting was a new one (not repainted) and its supporting layers (the clay and the plaster above it) were applied directly to the wall.

${ }^{72}$ One can observe a negative hollow and damages on the a fragment originating from the same room. This curved piece shows a red stripe on white background and it was presumably decorating the wall's footing (the stripe where the floor and the wall-painting meet). The painting on the footing preserved in situ has the same low quality, its surface is uneven and porous. The defects are rather consequences of the plaster's structure and composition and they are no traces of intentional wedging. 


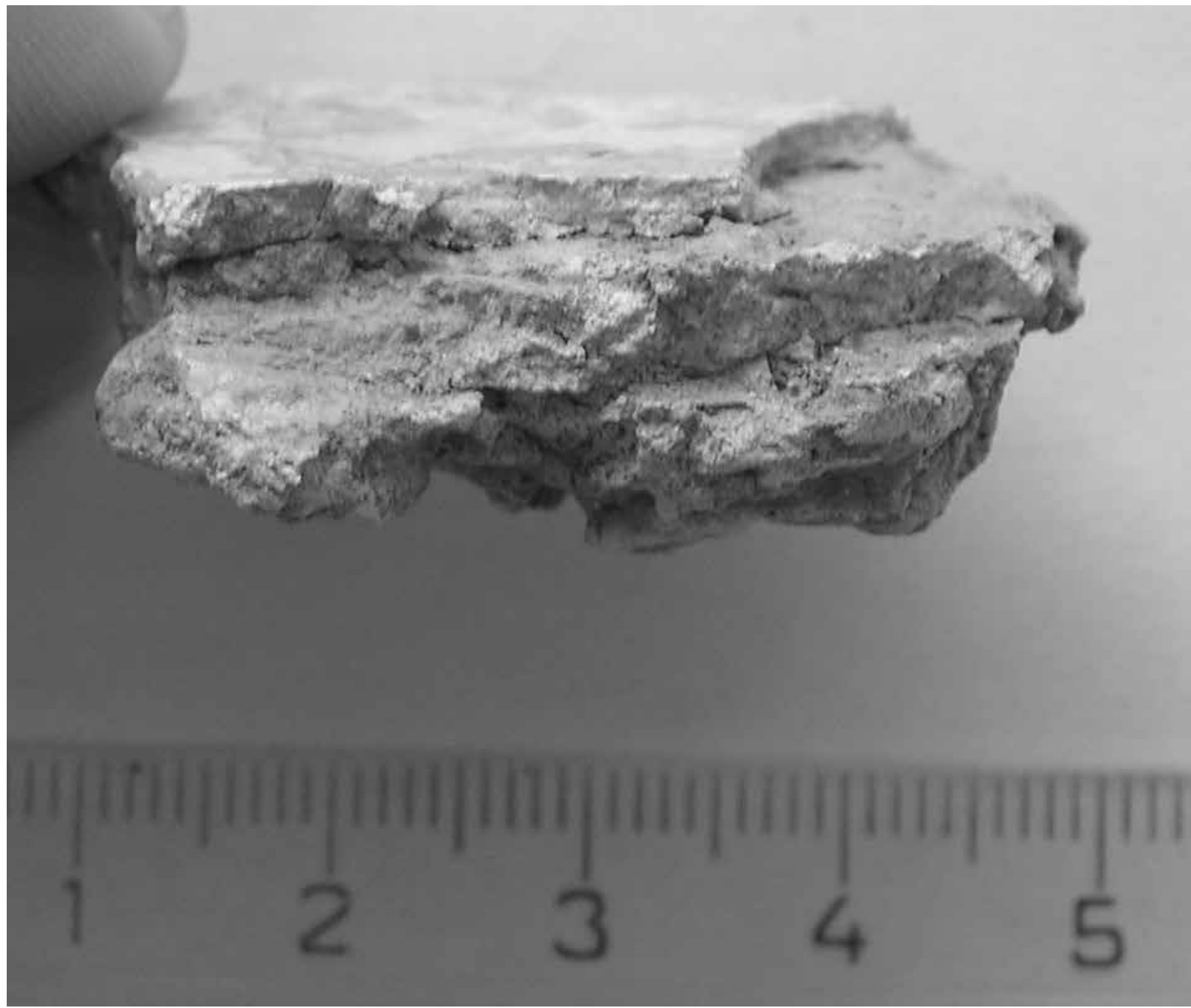

Fig. 12. Cross section of the wall-painting, with the lyers of the painting, close up

paintbrushes show an unordered clutter, from which rapid, clumsy, untraceable work can be deduced concerning the preparation of plaster and the ellaboration of the surface underlying the painting. ${ }^{73}$

Despite the "poor quality" of the primer layer, the figurative scene is a beautifully ellaborated work that reflects high craftsmanship with a multitude of shades and vivid colours. Amongst the colours applied on a white background, red and its shades dominate, such as reddish brown, dark brown or almost black shades over brown. Similarly several shades of red and pink appear on the painting on a red base, light is indicated with white colouring on top. A thick orangeish colour was used on the uncovered parts of the body. In addition, the use of yellow and green colours can be observed. Decorative motifs other than the figure and the inscription were made with one colour, red. The garlands are plain green, there was no aim to change colour or to make a more spectacular shading. The garland did not have an important role concerning the whole of the composition, they are more of a simple background or space filler.

The colours applied on the wall-painting were placed on the white base in the following order: first the colour of the body was put thickly on the mortar, then his red dress. ${ }^{74}$ The brownish reddish hair followed, empha-

${ }^{73}$ The wall-paintings originating from Sopianae, which are thought to be contemporary, have a different plaster, they cannot be compared to them. I would like to express my thanks to the Janus
Pannonius Museum for the possibility to study the wall-paintings found at Sopianae Square and the Basilica.

${ }^{74} \mathrm{We}$ find a discontinued white stripe at the figure's left 


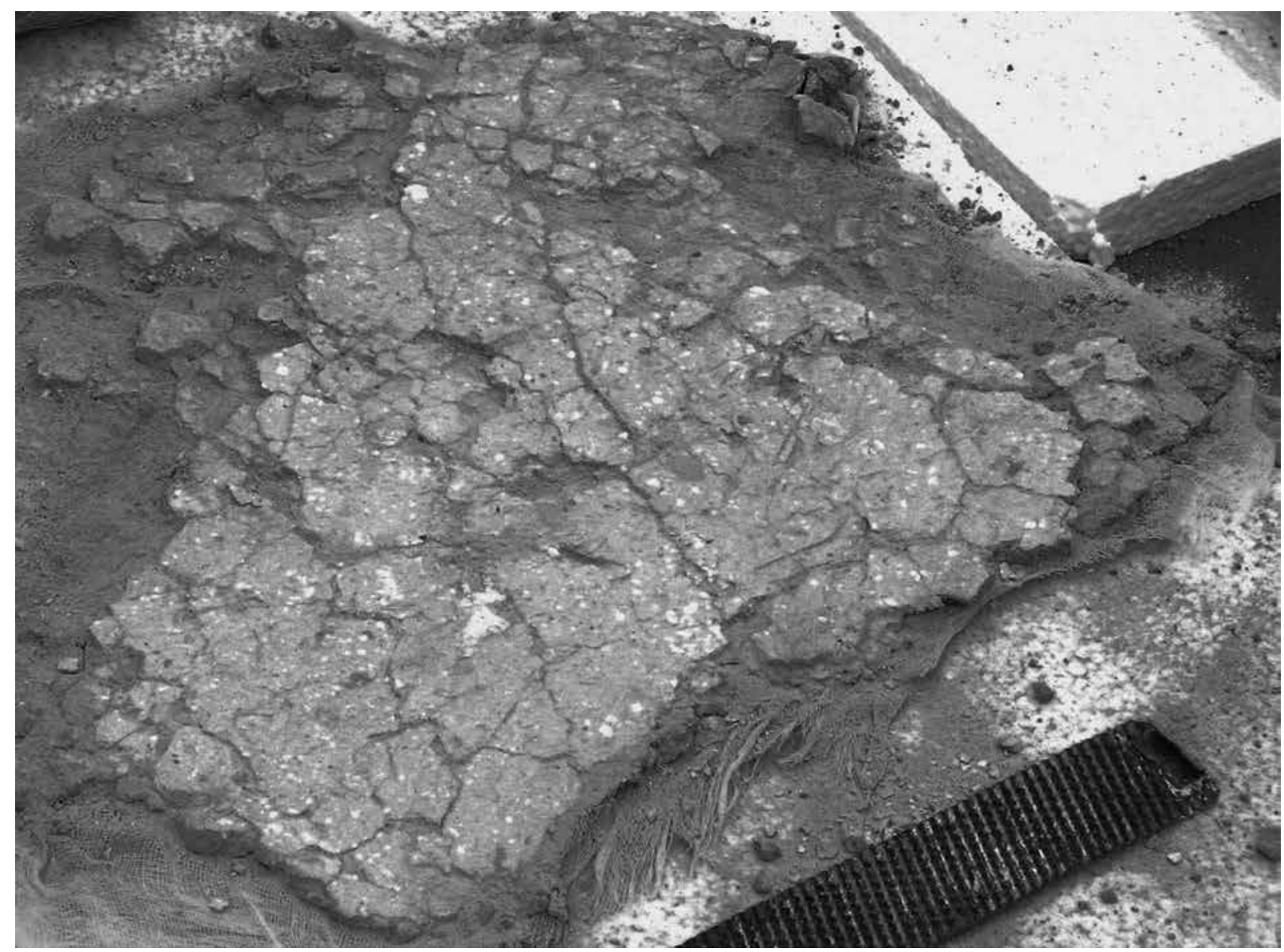

Fig. 13. Back side of the wall-painting isle picked up intact (photo: Zsolt Tóth)

sizing the curls with a dark brownish-blackish colour afterwards. Then the yellow crown and the basis of the cornuсорia with the grainstrikes were painted. The reddish brown colours of the cornucopia and the grainstrikes followed, for 3D effect and for lifelike presentation. Only then were the additional motifs of the painting, the green garland and then the yellow ribbon for binding the garland, and at last, the strip of the red frame put on the surface. Buon fresco technique was used in the beginning, and later, painting the smaller details, the pictor worked with fresco secco or guache technique. ${ }^{75}$

Painting the face of genius the paints were put on the surface in the following order (Fig. 8): above the thick layer of the colour of the skin, red and reddish brown colours were painted first. Then dark pink, pink, and at last white was applied to emphasize light and dark effects.

According to the results of $\mathrm{XRF}^{76}$ analisys of the paints, pink, ${ }^{77}$ purple, black ${ }^{78}$ and most red colours were painted using red soil paints containing a high amount of iron. The use of cinnabar ${ }^{79}$ is likely at the darker reds of the attire. Yellow-yellowish brown was made with the ose of ochre, green slate ${ }^{80}$ or glauconite. White originates of a lime base. ${ }^{81}$

${ }^{75}$ Concerning the painting techniques see: LING 1991, 204. For the identification of the paints' binder further material tests are needed.

${ }^{76} \mathrm{X}$-ray fluorescence analysis (XRF) is a non-destructive analytical technique based on ionization energy.

${ }^{77}$ Pink was obtained from the mixture of red and white. DEZSÖ-KAPOSVÁRI 2008, 2.
${ }^{78}$ The black colour was made with iron (hematite). DEZSŐKAPOSVÁRI 2008, 2

${ }^{79}$ On the cinnabar: Plin, Nat. hist. XXXIII. XL. 118-122; Vitr, De arch. VII. 9. 1-6.

${ }^{80}$ The low copper contents combined with high proportions of iron and potasium refer to the sericite mica. DEZSÖ-KAPOSVÁRI 2008, 2.

${ }^{81}$ DEZSŌ-KAPOSVÁRI 2008, 1-5.

Acta Archaeologica Academiae Scientiarum Hungaricae 69, 2018 
The wall-paiting was painted using three types of brushes. The smallest size ( 2 to $4 \mathrm{~mm}$ ) brush was used to paint the fine detailes of the face ${ }^{82}$ and the light and dark effects. ${ }^{83}$ Mid-size brush was used $(6-8 \mathrm{~mm})^{84}$ for the inscription ${ }^{85}$ and the largest, thickest brush was used for painting the leaves of the garland. The first two, thinner brushes were used by the pictor imaginarius painting the details of the figure of genius, while painting more simple, repetitive motifs thicker brush was used. The face and the body turns slightly right, which move is marked with the light and dark effect. ${ }^{86}$ The eye-white of the figure has gotten a bright white highlight.

There are more points, marks in the plaster (mortar) to designate the position of the figure on the sidewall. One of these marks is in the centre of the head of genius $^{87}$ the other is observed at the point, where cornucopia and the green garland meets. The points marked on the plaster are roughly in one line spaced $18.5 \mathrm{~cm}$ apart. ${ }^{88} \mathrm{I}$ do not consider the longer, horizontal, deep scratch on the face, right of the mouth line ${ }^{89}$ deliberate mark, rather a sign of vandalism, or other injury, which greatly destroys the overall look of the portrait and the wall-painting. (Fig. 8)

\section{THE MEANING, ROLE, TYPES AND REPRESENTATIONS OF GENIUS IN REGARDS OF GENIUS OF KOSSUTH SQUARE}

Originally genius was an impersonified deity, embodying vitality and manpower. ${ }^{90}$ It was believed that every man has his own guardian (Iuno in the case of women) who accompanies, cares for him all his life, and is commemorated on every birthday. In the family the genius of Pater familias helped the family gain. In addition, there was a genius for the senate (genius Senatus), family, collegia, the Roman people themselves (genius populi Romani), military units, occupations (eg. genius commercii et negotiantium ${ }^{91}$ ), as well as the places (genius loci, who could also appear as a snake ${ }^{92}$ ) and buildings (theatrum, thermae, macellum, horreum, etc.). ${ }^{93}$ In the meantime often cites (genius urbis Romae, genius c(oloniae) C(laudiae) S(avariae $\left.{ }^{94}\right)$ ) or whole provinces (genius Daciarum $\left(\right.$ trium $\left.^{95}\right)$ ) had their own guarding deity. Later on, the genius of the emperor (genius Augusti) became the most prominent genius, securing the empire's prosperity. ${ }^{96}$ Good genius was thought to be a winged childlike figure, wearing a wreath made of flowers and grainspikes. ${ }^{97}$ We can expect genius portraits from the late Republican period until $392 \mathrm{AD}$ the decree of Theodosius ${ }^{98}$ banning the worship of the cult in $392 \mathrm{AD} .{ }^{99}$

Genii appearing on wall-paintings were most commonly depicted along with Lares, ${ }^{100}$ on the walls of house shrines, ${ }^{101}$ or in fully painted lararies,${ }^{102}$ but they could also appear at the eye-height of sidewalls as float-

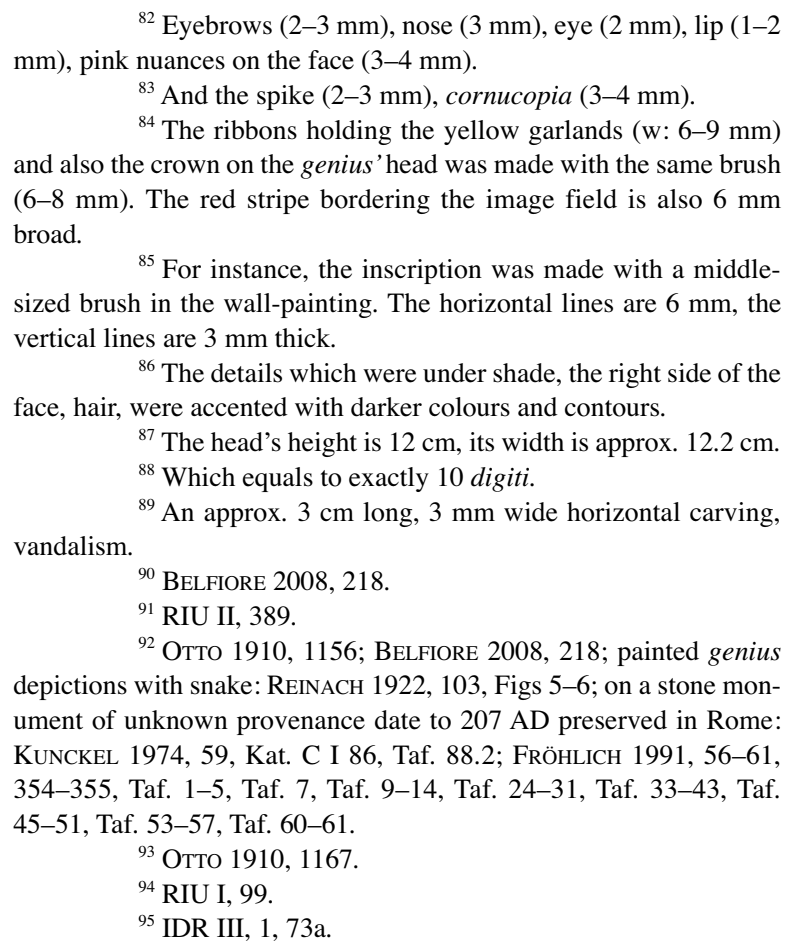

${ }^{82}$ Eyebrows (2-3 mm), nose ( $\left.3 \mathrm{~mm}\right)$, eye ( $\left.2 \mathrm{~mm}\right)$, lip (1-2 $\mathrm{mm})$, pink nuances on the face $(3-4 \mathrm{~mm})$.

${ }^{83}$ And the spike (2-3 mm), cornucopia (3-4 mm).

${ }^{84}$ The ribbons holding the yellow garlands (w: 6-9 mm) and also the crown on the genius' head was made with the same brush $(6-8 \mathrm{~mm})$. The red stripe bordering the image field is also $6 \mathrm{~mm}$ broad.

${ }^{85}$ For instance, the inscription was made with a middlesized brush in the wall-painting. The horizontal lines are $6 \mathrm{~mm}$, the vertical lines are $3 \mathrm{~mm}$ thick.

${ }^{86}$ The details which were under shade, the right side of the face, hair, were accented with darker colours and contours.

${ }^{87}$ The head's height is $12 \mathrm{~cm}$, its width is approx. $12.2 \mathrm{~cm}$.

${ }^{88}$ Which equals to exactly 10 digiti.

${ }^{89}$ An approx. $3 \mathrm{~cm}$ long, $3 \mathrm{~mm}$ wide horizontal carving, vandalism.

${ }^{90}$ BELFIORE 2008, 218.

${ }^{91}$ RIU II, 389.

${ }^{92}$ OtTo 1910, 1156; Belfiore 2008, 218; painted genius depictions with snake: REINACH 1922, 103, Figs 5-6; on a stone monument of unknown provenance date to $207 \mathrm{AD}$ preserved in Rome: KunCKel 1974, 59, Kat. C I 86, Taf. 88.2; FröHLICH 1991, 56-61, 354-355, Taf. 1-5, Taf. 7, Taf. 9-14, Taf. 24-31, Taf. 33-43, Taf. 45-51, Taf. 53-57, Taf. 60-61.

${ }^{93}$ Отто 1910, 1167.

${ }^{94}$ RIU I, 99.

${ }^{95}$ IDR III, 1, 73a.

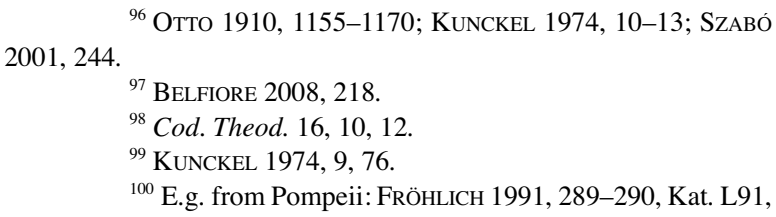

${ }^{100}$ E.g. from Pompeii: FröHLICH 1991, 289-290, Kat. L91, VII. 12.11, Taf. 1; FröHLICH 1991, 252-253, Kat. L 8, I. 8.8, Taf. 2/1 FrÖHLICH 1991, 279, Kat. L70, VI. 15.1, Taf. 7; FrÖHLICH 1991, $291-$ 292, L96, VII. 5.37, Taf. 8/3; FRÖHLICH 1991, 292, Kat. L98, Taf. 10/2; FRÖHLICH 1991, 298, Kat. L109, IX. 13.1-3, Taf. 14/2; FrÖHLICH 1991, 251, Kat. L5, I. 7.10-12, Taf. 24/1; FRÖHLICH 1991, 254, Kat.: L11, I. 8, Taf. 26/2; FröHLICH 1991, 261, Kat. L29, I. 13.2, Taf. 28; FRÖHLICH 1991, 267-268, Kat. L44, V. 2.b/c, Taf. 31/2; FrÖHLICH 1991, 278, Kat. L67, VI. 11.10, Taf. 36/2; FRÖHLICH 1991, 289, Kat. L90, VII. 12.10, Taf. 44/2; FRÖHLICH 1991, 299, Kat. L111, IX. 14 2/4, Taf. 48/1; FRÖHLICH 1991, 272-273, Kat. L54, V. 4.b, Taf. 34/3; FRÖHLICH 1991, 276, Kat. L61, VI. 6.1, Taf. 35/1; FRÖHLICH 1991, 296, Kat. L105, IX. 5.2/22, Taf. 49/2; BoyCE 1937, Kat. IX. 420; FRÖHLICH 1991, 298-299, Kat. L110, IX. 1.3, Taf. 50/2; FRÖHLICH 1991, 339, Kat. F71, IX. 12.7, Taf. 58/2.

${ }^{101}$ E.g. in Pompeii, the lararium of House nr. I. 16.3 was decorated with a wall-painting on the back wall of the household shrine: FRÖHLICH 1991, 264, Kat. L35, Taf. 5.2-3; also in Pompeii, Casa del Larario del Sarno, Pompeii I. 14. 6/7, FRÖHLICH 1991, 262 263, Kat. L33, Taf. 5.1, Taf. 6.

${ }^{102}$ Some more lararii created solely by paintings: from the House of the Vettius (VI. 15.1.): REINACH 1922, 103, Fig. 3; also from 
ing figures. ${ }^{103}$ Genius' characteristic attributes are the cornucopia, acerra, possibly rotulus, ${ }^{104}$ held in their left hand, with their right hand, they usually offered patera to the altar often displayed next to them. ${ }^{105}$ The attire initially was only toga,${ }^{106}$ often put above the head (capite velato), ${ }^{107}$ later a cloak and only rarely toga. According to $\mathrm{H}$. Kunckel, from the $2^{\text {nd }}$ century $\mathrm{AD}$ on genius representation the wearing of a toga decreases and is almost completely disappearing except for the genius of the Senate. ${ }^{108}$ However, the fact that the form of a genius wearing toga still appeared even in the $3^{\text {rd }}$ century AD suggests that this form lived on. ${ }^{109}$ The simultaneous occurrences of a genius wearing a toga ${ }^{110}$ and a cloak are confirmed by the Saalburg stone monuments, ${ }^{111}$ among which, concerning the development of the head, the facial expression the cloaked genius can be parallelled with the genius of Pécs. The genius was depicted wearing a crown or a wreath or possibly a modius on his head. ${ }^{112}$ The crown made of walls on the head symbolized the place (genius loci), a walled city ${ }^{113}$ or military facility. ${ }^{114}$ Genius was represented initially as an elderly man, later in the $2^{\text {nd }}-3^{\text {rd }}$ centuries, they were more depicted as a young man. ${ }^{115}$

The general collateral of the painted versions of genius depictions are garlands, ${ }^{116}$ often made of leaves of two or more colours, flowers and fruits, arched, similar to that of the Pécs wall-paintings. In addition, the genius is frequently depicted on coins ${ }^{117}$ and stone monuments. ${ }^{118}$ Furthermore, the theme of genius was also popular in Roman mosaics. On the $3^{\text {rd }}-4^{\text {th }}$ century mosaic of Thugga, North Africa that decorated the oecus of the so called House of Seasons, a genius is depicted as the guarding deity of the city, wearing a tunica with a crown symbolizing city walls on his head, and a cornucopia in his left hand. ${ }^{119}$ Illustrating the genius of the year was also a popular topic of mosaics, amongst others we know its $2^{\text {nd }}$ century examples of bust depictions of Thysdrus ${ }^{120}$ and the Aranjuez ${ }^{121}$ of Spain.

Pompeii: ReINACH 1922, 104, Fig. 2; with Lares on both side (VIII. 2. lararium): BALDASSARRE et al. 2002, 250; and the lararium of the house of Iulius Polybus (IX.13.3.): FröHLICH 1991, 298, Kat. L109, Taf. 14. 2; RANIERI PANETTA 2005, 108. In the tavern of Vetutius Placidus (I. 8.8.) with Iupiter: REINACH 1922, 8, Fig. 1; with Hercules: REINACH 1922, 186, Fig. 2; from the area the Diana temple of Tifata, Italia: ReINACH 1922, 103, Fig. 1. Painted lararium of Pompeii: KunCKEL 1974, 82-85, Taf. 29-35; FRÖHLICH 1991, 1-370.

Lararium known from Pannonia: From Bakonya in the surroundigs of Pécs: GÁBOR 2003, 2-3. Bronze statuettes, jug, oil lamp from Nagydém: Thomas 1964, 5-31; lararium of Tamási: THOMAs 1963, 6-12; the lararium of Sárszentmiklós: BÁNKI 1984, 83-85, Taf. XL-XLII; lararium excavated at Budapest III, Dugovics T. Square, painted, decorated with stucco: KÉRDỏ 1985, 36, No. 66/4, the wall-painting assembled together is unpublished, Aquincumi Múzeum, Roman Collection: GYRFS 2964; the lararium from Tétény: Fitz 1998, 75, Kat. 65-55; from Poetovio: FiTz 1988, 75, Kat. 67, and from Bácsa: FiTz 1988, 75, Kat. 68.

${ }^{103}$ E.g. in Pompeii in the House of Zephyr and Flora (VI. 10.11.8.9.): REINACH 1922, 148, Fig. 3.

${ }^{104} \mathrm{H}$. Kunckel has classified the $1^{\text {st }}$ century BC $-1^{\text {st }}$ century $\mathrm{AD}$ Genius familiaris depictions according to the items held in their hands: KunCKEL 1974, 19.

105 OтTо 1910, 1161; also depicted on coins along with an altar: BíRÓ-SEY 2002, 37.

${ }^{106}$ Wearing the toga was generally an attribute genius of the emperor, but also typical to the genius of private persons: Отто 1910, 1164.

${ }^{107}$ Отто 1910, 1161.

${ }^{108}$ KUNCKEL 1974, 61.

${ }^{109}$ KuncKel 1974, Kat. C I 54, C I 100, C I 109, C I 113,

C I 126.

${ }^{110}$ Genius centuriae.

${ }^{111}$ Mattern 2001, 178, 180, Abb. 1, Abb. 2.

112 KunCKEL 1974, 56, Kat. C II 1, Taf. 90, Taf. 1-96; with a crown of walls: Отто 1910, 1168.
${ }^{113}$ E.g. depiction of the guardian of the city, its genius on mosaic from Thugga: SALOMONSON 1974, Kat. 26

${ }^{114}$ KUNCKEL 1974, 61.

115 OtTo 1910, 1166; KunCKEL 1974, 54.

${ }^{116}$ See FröHLICH 1991, Taf. 1-2, Taf. 7, Taf. 8/3, Taf. 10, Taf. $14 / 2$, Taf. $24 / 1$, Taf. 25 , Taf. $26 / 2$, Taf. 28 , Taf. $31-32$, Taf. $35 / 1-$ 37, Taf. 44/2, Taf. 49-52, Taf. 58/2.

${ }^{117}$ Genius representations on coins: naked, partially cloaked or toga-wearing male figure, holding a patera in his right hand, a cornucopia in his left hand and sometimes flanked by an altar: BíRÓ-SEY 2002, 37, Figs 160-164. In two instances he can be seen with a different crown on his head: BíRó-SEY 2002, Figs 160, 162. A concise treatise on the coin depictions of the Roman Empire in the $3^{\text {rd }}$ century AD: KunCKEL 1974, 64-67, 116-133, Taf. 1-7.

${ }^{118}$ The genius head fragment from Aquincum, the Governor's Palace, wears a corona muralis: KUZSINSZKY 1934, 95-96, Abb. 42; FACSÁDY-ZsIDI 2001, 118, Kat. 275; one from the Military Town from the $2^{\text {nd }}$ century AD: VÁMOS 2012, 361-373; VÁMOS 2008, 251258; from Vindobona: HARL 1999, 6-14. Sculptures, reliefs, statuettes, bronze or other metal statutes are discussed at KUNCKEL 1974, 78-115, Taf. 8-95.

${ }^{119}$ Yacoub 1970, 90, A. no. 387; SALOMOnSON 1974 ,

Kat. 26.

${ }^{120}$ The figure wears an attire only thrown over his left shoulder only: PEDRAZ 2006-2007, 472-473, Fig. 2.

${ }^{121}$ Galiano et al. 1986-1987, 175-183, Fig. 1-2. In this paper all the excavated mosaics depicting the genius of the Year were projected on the map of the Roman Empire. The sites mentioned in the paper are the following: Volubilis, Hippo Regius, Haïdra, Dougga two times, Carthago, El Djem, Itálica, Aranjuez, Ostia, Sentinum, Rome. GALIANo et al. 1986-1987, 175-183, Fig. 5. A mosaic depicting Abundantia (or a genius?) is known from Hispania, from Santervás del Burgo (Soria). A mosaic depicting Abundantia (or a genius?) is known, as well: PIQUERo 2008, 1266-1267, Tav. II. a. 
The wall-painting decorated one of the rooms of a larger building. Its making can be connected to the last refurbishing, painting period ${ }^{122}$ of the building in the first half of the $3^{\text {rd }}$ century (in Severan Age) or later. It got into the rubbish layer around $260 \mathrm{AD}$, at the time of the devastation of the building.

The full body depiction ${ }^{123}$ of the genius is composed on a white base, situated in the centre of the northern wall of the room. It was put on a flat surface, the base mortar is not curved. The draftable size of the figure is smaller, about half the size of real human-size. The wall-paintings of the end of $2^{\text {nd }}$-the beginning of $3^{\text {rd }}$ century AD are characterized by the appearance of taller human figures (servants, mythological scenes, goddesses, etc.) sometimes even filling the whole frame on the side walls. Similar semi- or full-scale figurative scenes are known from Rome, ${ }^{124}$ from the Roman Empire, for example in the eastern provinces: Zeugma ${ }^{125}$ and Ephesos, ${ }^{126}$ and Gallia: Saint-Romainen-Gal ${ }^{127}$ and Pannonia: from Brigetio. ${ }^{128}$

In order to fix the shape of the figure on the wall, there were several circular ${ }^{129}$ points encarved in the mortar. The genius wears a yellow-painted crown (corona muralis or corona aurea) on his head. Supposing his crown is gold, the similar colour of the cornucopia assumes a more noble material, its monochromic background was decorated with a twisting tendril motif. Pinecone and grainspike are depicted in the cornucopia. According to analogies the figure perhaps held a patera in his other, outstreched hand, the contents of which could be poured onto a small altar as a sacrificial offer. The rest of the figure is fragmented, with a thick red cloth or shawl on the left shoulder and beneath the cornucopia referring to his attire. Most contemporary analogies are characterized by the red cloak (pallium) covering part of the body. This type of depiction became widespread in the $2^{\text {nd }}$ century AD. This so-called new genius type carried a characteristic cornucopia in his left hand, a patera in his right, wearing a crown (corona muralis) on his head. This representation was primarily related to genius depictions of larger public organizations, bodies, associations, collegia like genius loci, or genius militaris. ${ }^{130}$ The red attire on the wall-painting, as it seems at the moment, based on the arrangement of the plaits, can be made up to a toga. Reddish purplish toga (toga purpurea) was usually considered the attire of gods.

The red colour two-line inscription, clearly identifying the figure, was situated in all probability in the small curve above the garlands, either on the right of the figure or above.

The genius stands in the foreground, and because of the garlands running by his two sides, close to his head, it is possible to exclude a possible image of another deity standing directly by him. ${ }^{131}$ However, other figurative portraits can be imagined among the curves of the garlands. Greater part of the room and the decorative wallpaintings have been destroyed, but on the basis of remaining fragments we can neither exclude nor verify the

122 The excavator assumes that the room was remodelled at least one time: ТóTH 2008, 9. The wall-painting was made in the last construction phase of the room.

${ }^{123}$ Due to the features of painting (the garlands and their placement, the figure and the size of the painting, the type of the paint and the surviving fragments) we can dismiss that the genius was depicted as a torso.

${ }^{124}$ BARBERA-PARIS 1996, 122-130, 158-166, E 32-33. Tav. I-II; From Rome also in the triclinium of the Domus Praeconum: WIRTH 1934, 125-129, Pl. 29-31; BALDASSARRE et al. 2002, 347; also from Rome, larger figures serving food: REINACH 1922, 250. Figs 4-9; also from the Cryptoporticus of Via Friuli: MiELSCH 2001, 111, Abb. 128; from Ostia: MiELSCH 2001, 111, Abb. 129.

${ }^{125}$ Full body depictions: BARBET 2005, 25-37, 47-54, 144-157, 159-168. Maison de Poséidon (P11, P23): Pl. II-III, V-VI, Pl. A, Pl. C, Pl. E; Maison de l'Euphrate (P26): Pl. XXIII-XXIV, XXVI.3, XXX, Pl. J, Pl. K; Maison sans Mosaïque (P30): Pl. XXV; Pl. O; Pl. P; from Ephesos: Pl. P.

${ }^{126}$ Hanghaus 2, so called: „Theaterzimmer”, triclinium: ZIMMERMANN-LADSTÄTTER 2010, 113-119, Abb. 195.1, 200-203, 206. Full body depictions of servants from the late Roman period, first half of $4^{\text {th }}$ century AD, from Odeon-Hanghaus: ZIMMERMANNLADSTÄTTER 2010, 168, Abb. 349-350.
${ }^{127}$ BARBET 2008, 266-267, Fig. 414-416. Smaller wallpainting fragments referring to a full body depiction were found in Gallia, in Lisieux, Chartres, Évreux, Paris: BARBET 2008, 268-276.

${ }^{128}$ Servant figures: BoRHY et al. 2010, 83-117, 3, Fig. 11. and 6.

${ }^{129}$ Presumably inscribed using compasses.

${ }^{130}$ Summarizing depictions: LIMC VIII 1 (1997) s. v. Genius 602-604, No. 19-44 (I. Romeo), and KUNCKEL 1974, 53-72, 100-115, C I-II. Crown of walls or crown of rays, wreath or modius: KunCKEL 1974, Taf. 12, 45, 67.3, 68.1, 3, 69 1, 70, 72.1, 74.2, 75.4, $77.2,90-96$. Stone monument linked to beneficiarius from the camp of Altrip of Germani, mentioning two different genii on its inscription dated to $181 \mathrm{AD}$. In this case genius is wearing a wreath on his head: KunCKEL 1974, 55, Kat. C I 2, Taf. 68.1.

${ }^{131}$ FrÖHLICH 1991, 129-164, Iupiter, Iuno, Venus, Mars, Bacchus, Minerva, Fortuna, Mercurius, Hercules, Priapos, Lares, Penates; along with Minerva and depiction of eagle: KunCKEL 1974, 57, 102, Kat. C I 21, Taf. 70,1; with Victoria: BARBET 2008, 264, Fig. 410-411; with Iupiter: REINACH 1922, 8. Fig. 1; with Epona: the Epona altar was erected around 210 AD by beneficiarius, on which beside Epona genius Leucorum is pictured as well: KUNCKEL 1974, 63 , Kat. C I 4. 


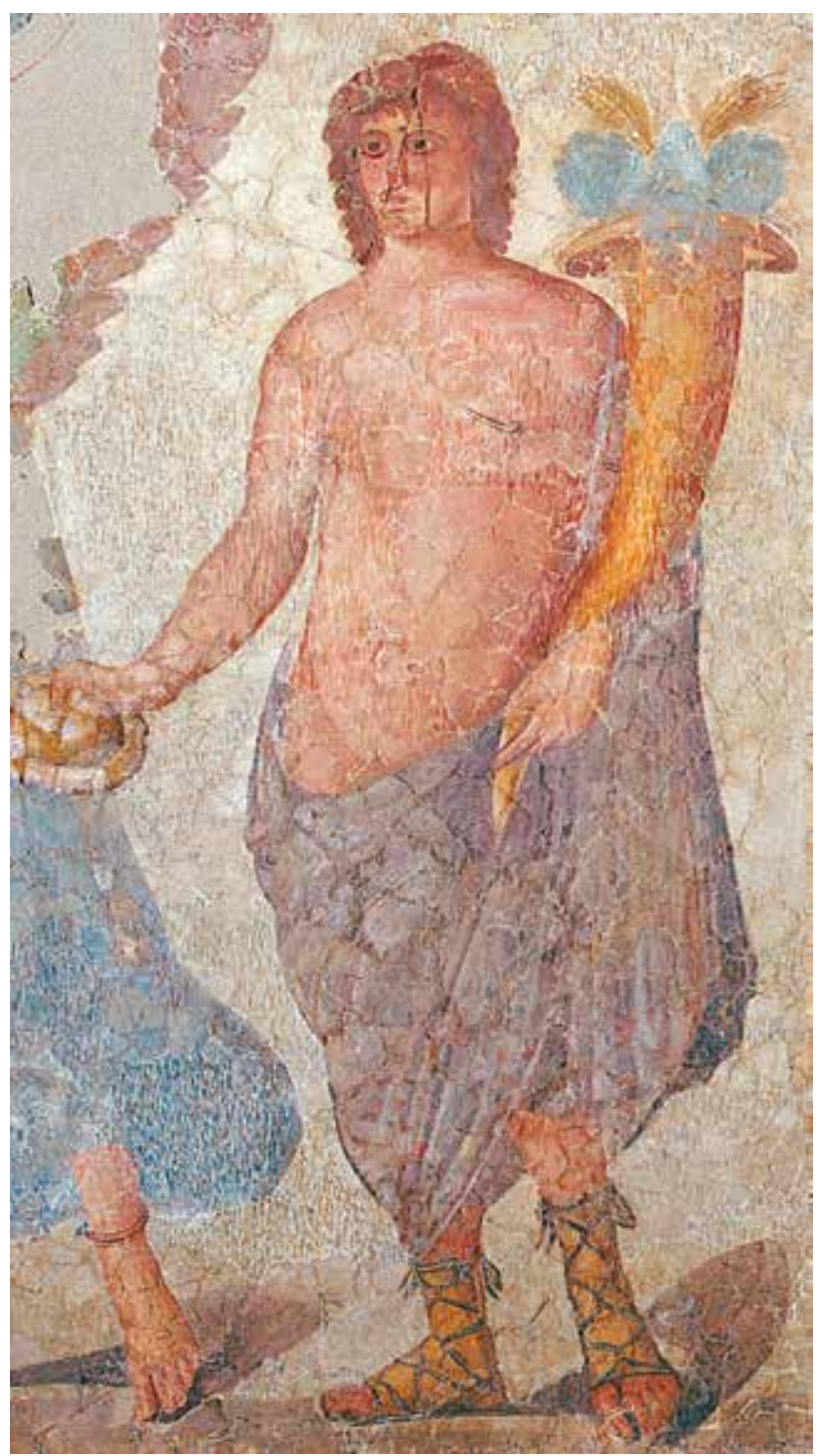

Fig. 14. Depiction of genius from Narbonne

(photo: (C) Photo collection Gaud, Palais des archevêques, ville de Narbonne)

possibility the wall-painting being a part of a painted lararium. Typically in a lararium beside the central genius figure there is the depiction of lares on both sides. However, since no fragments referring to lares or any other deities have been found, they are not present in the proposed reconstruction.

Based on the arch of the garlands leaning on both sides of the figure, the width of the side surface had to be at least $177-180 \mathrm{~cm}$. In the case if there were lares or other figurative motifs in the composition, we can calculate an about a $355 \mathrm{~cm}$ length concerning the northern wall. The head of the figure had to be at eye level or somewhat higher, that's what the complete height of the wall-painting can be related to. It can be estimated 280 to $300 \mathrm{~cm}$. In drawing the wall-painting the measure of one and a half Roman foot was used. ${ }^{132}$

The mortar of the wall-painting, the simple white background is of low quality, fast work, while the figure of the painting is colourful and its face is a portrait-like, precise work. The preparation of the mortar was probably done by local, unskilled labor force, before the pictor imaginarius and his apprentice (pictor parietarius), who

${ }^{132}$ One and a half Roman foot $=44.4 \mathrm{~cm}$. The height of the

of the garlands is approx. $2 \times 1.5$ Roman foot. The footing can be figure is approx. $2 \times 1.5$ Roman foot, the distance between the stalks drafted to about $1 \times 1.5$ Roman foot. 
would produce simple repetitive motifs such as grass, the strip of thin red frame and paint the inscription would complete the work. ${ }^{133}$ It is interesting to note that garlands, usually consisting of multiple colours or at least showing light-shadow effects, were made using a single colour, green ${ }^{134}$ on this wall-painting. The motif painter used three paints, red, green and yellow. The simple red stripe and the linear design surrounding the picture as a frame also refers to putting the wall-painting discussed in the category of simpler, smaller budget paintings, as opposed to the full-bodied genius depictions with Victoria-Virtus ${ }^{135}$ (genius Augusti ${ }^{136}$ ), from the aedicula of Narbonne, France. (Fig. 14) The hairstyle, gaze, the posture and the elaboration of the Narbonne figure are exactly the same as of the genius depicted in Sopianae. The Narbonne figure also holds a cornucopia in his left hand in which blue-painted pinecones and grainstrikes leaning in two directions are displayed. ${ }^{137}$ However the Narbonne figure does not wear a symbol on his head, and his attire, a blueish cloak only covers his lower body and his hand holding the cornucopia. It is also dated to the end of $2^{\text {nd }}$-beginning of $3^{\text {rd }}$ century $\mathrm{AD},{ }^{138}$ and is linked to imperial cult and imperial propaganda. ${ }^{139}$ Similar to the genius of Pécs, a $1.61 \mathrm{~m}$ tall statue of a stone-sculpted genius standing on a inscripted base was found in Heddernheim, which was dated to $230 \mathrm{AD} .{ }^{140}$ Furthermore, the genius of a stone monument found in Carnuntum can be paralelled to the wall-painting of Sopianae. ${ }^{141}$ This genius wears a crown, has longer curly hair and is accompanied by the depiction of Minerva and an eagle. The similar genius found in Mainz encarved on the Iupiter altar wearing a toga is likely to be considered the genius of the emperor. ${ }^{142}$ The fragmented bronze statuette ${ }^{143}$ depicting the genius of Brigetio, also dating back to the beginning of the $3^{\text {rd }}$ century AD was made using similar terms as the genius of the wall-painting of Pécs. The depiction on the denar genius p(opuli) R(omani) minted by Septimius Severus in in 194 AD, because of his similar posture, longer hair and the headdress (a wreath?) and the attributes (cornupia, patera) held in his hands, can also be connected to the wall-painting of Pécs. ${ }^{144}$

As of the role of genius the second line of the iscription could inform us, but being fragmented, its interpretation is uncertain. ${ }^{145}$ The hairdress on the head is not the usual, in most cases rectangular one, depicted with protruding towers (corona muralis), rather an opened, wider headdress made of straps, likely a corona aurea, as its yellow colour might indicate. According to the statuette of an eagle, and the possible corona aurea this depiction of genius is likely a genius Augusti. ${ }^{146}$ Under Septimius Severus, at the age this wall-painting is dated to, the inscription genius Augusti is missing on the image of the coin. Instead genius $p\left(\right.$ opuli) $R$ (omani) is typical, ${ }^{147}$ by the same iconography as it is of our wall-painting. Thus it is probable, that the expression Augusti was ommitted from the contemporary wall-painting as well.

The poor preparation of the foundation, the poor quality of the mortar, the simple construction of the background and the subtle linear framing of the figurative representation do not indicate a representative room, as opposed to the throughoutly ellaborated, richly colourful figure. From the $2^{\text {nd }}$ century onwards more depictions of the genius belonged to organisations, it is possible that the figure depicted on the wall painting was a collegium genius, and the room functioned as the sanctuary of the collegium's seat. The interpretaion of the crown on the head as a corona or corona muralis brings up the idea of genius' city protecting role (genius loci). The composition being a painted lararium is less probable since neither remaining fragments nor their painting refer to the presentation of any niche, lararium or Lares.

The room, the topic of its wall-painting, the eagle statuette, and the existence of a stone basis refer to this room being a santuary. Earlier, during the excavation of Gábor Kárpáti on Sopianae Square, the sanctuary of the

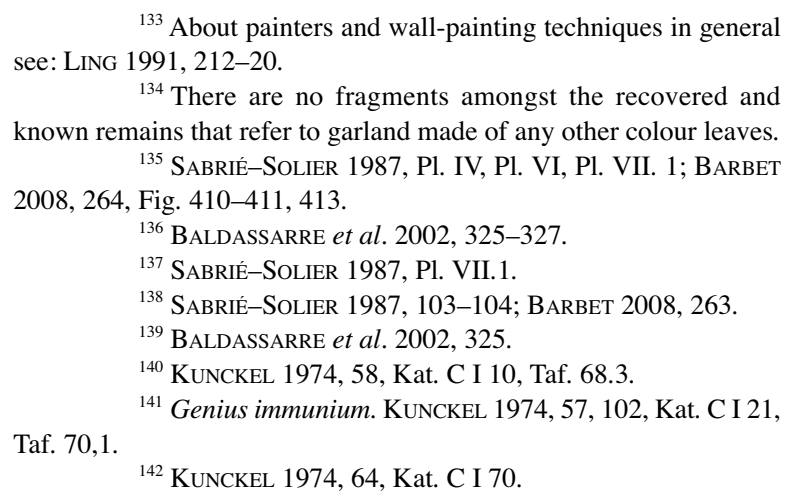

${ }^{143}$ KunCKel 1974, 70, Kat. C II 26, Taf. 96. 4. Also alike: KunCKel 1974, Kat. C II 24, Taf. 96. 1; Kat. C II 10, Taf. 92.1; BARTus 2015, 85-86, Kat. 69, plates 51-54.

${ }^{144}$ KunCKEL 1974, 47, 117, M I 18, Taf. 2.6

${ }^{145}$ Possible interpretations see below in the appendix-paper of B. Fábián and Á. Szabó.

${ }^{146}$ The representation of the figure in half a man size is not deemed to be specific among contemporary wall-paintings. See footnotes nr. 124-128. The type of the red attire (toga or pallium) cannot be decided undoubtedly, can be guessed only based upon analogies, no far-reaching conclusions can be drawn.

${ }^{147}$ On the denar minted in $174 \mathrm{AD}$, genius' hairstyle, posture is really close to the wall-painting discussed. The young genius figure standing by the altar is depicted with long hair, a wreath on his head, a shawl covering his lower body, holding a cornucopia in his left, 
beneficiarius of the legio II Adiutrix was already identified, ${ }^{148}$ up to this date that was the only sanctuary from the $3^{\text {rd }}$ century that exact place was known in Sopianae. ${ }^{149}$ The genius of the wall-painted room on excavated in 2008 by Zsolt Tóth in Kossuth Square may be the second one that presumably depicts the genius of crew of the tollhouse. ${ }^{150}$

\section{REFERENCES}

\section{Cod. Theod \\ FiRKák}

ALFÖLDI 1942

BALDASSARRE et al. 2002

BÁNKI 1984

BARBERA-PARIS 1996

BARBET 2005

BARBET 2008

BARBET 2009

BARTUS 2015

BELFIORE 2008

BíRÓ 2001

BíRÓ-SEY 2002

BORHY et al. 2010

BoYce 1937

Catullo 2000

DEZSŐ-KaPOSVÁRI 2008

FACSÁDY-ZSIDI 2001

FARKAS-KÖHEGYI 2002

FITZ 1976

FiTZ 1993-1995

FITZ 1998

FÜLEP 1974

\section{Codex Theodosianus}

Fiatal Római Koros Kutatók Konferenciakötete [Conference Volume of Young Researchers of the Roman Age]

$=$ A. AlFöLDI: Aquincum a későrómai világban [Aquincum in the late antique world]. In: Budapest története. I.: Budapest az ókorban. Ed. K. Szendy. Budapest 1942, 670-746.

$=$ I. BaldassarRe-A. Pontrandolfo-A. Rouveret-M. SALVAdori: Pittura romana. Dall'ellenismo al tardo-antico. Milano 2002.

= Zs. BÁNKI: Bemerkungen zum Lararium von Sárszentmiklós. Alba Regia 21 (1984) 83-85.

$=$ M. BARBERA-R. PARIS: Antiche stanze. Un quartiere di Roma Imperiale nella zona di Termini. Roma 1996.

= A. BARBET (dir.): Zeugma II. Peinture murales romaines. Varia Anatolica 17. Paris 2005.

= A. BARBET: La peinture murale en Gaule Romaine. Paris 2008.

= A. BARBEt: La peinture murale romaine. Les styles décoratifs Pompéiens. Paris 1985. $-2^{\mathrm{e}}$ édition, revue et corrigée, Paris 2009.

$=$ D. BARTUS: Bronzistenek. Római kori figurális bronzplasztika Brigetióban [Bronze Gods. Roman figural bronzes from Brigetio]. ActaArchBrig I/8. Komárom 2015.

= J-C. BELFIORE: A görög és római mitológia lexikona [Dictionnaire de mythologie grecque et romaine]. Debrecen 2008.

= E. BíRó: II. századi falfestmény Brigetioból (Szőny, Komárom-Esztergom megye). A Kuny Domokos Múzeum állandó kiállitása. Kiállításvezetô $\left[\mathrm{A} 2{ }^{\text {nd }}\right.$ Century Wall-Painting from Brigetio. Exhibiton guide]. Tata 2001.

= K. Bíró-SEY: Bevezetés a római pénzek gyüjtésébe. Császárkor (Einführung in das Sammeln römischer Münzen, Kaiserzeit). Vác 2002.

= L. Borhy-E. Harsányi-L. O. Kovács-Zs. Kurovszky-A. Paetz gen. Schieck-J. PásztókaiSZEỎKE-E. SZÁMADÓ: A III. számú épület (Komárom/Szőny-Vásártér 2.) falfestményei [Wallpaintings of building No. III (Komárom/Szőny-Vásártér 2.)]. In: Római kori falfestmények Brigetioból. ActaArchBrig I/3. Komárom 2010, 83-117.

= G. K. BoYCE: Corpus of the Lararia of Pompeii. MAAR 14. Rome 1937.

= L. CATUllo: The Ancient Roman Villa of Casale at Piazza Armerina: past and present, Morgantina. Messina 2000

= J. Dezső-F. Kaposvári: Jelentés a Pécs, Kossuth tér feltárásán talált freskótöredék festékanyag vizsgálatáról [Report on the Frescoe Fragments for Dyestuffs from the Excavation at Pécs, Kossuth tér]. Pécs 2008.

$=$ A. FACSÁDY- P. ZsIDI (dir.): Romains de Hongrie. $\mathrm{I}^{\text {er- }} \mathrm{V}^{\mathrm{e}}$ siècles après J.-C. Exposition produite par le Département du Rhône, Musée de la Civilisation gallo-romaine de Lyon en collaboration avec le Musée Historique de Budapest dans le cadre de la Saison hongroise en France. Musée de la Civilisation gallo-romaine, Lyon, décembre 2001 - mai 2002. Lyon 2001.

$=$ E. FARKAS-M. KỏHEGYI: A szemelyi és pellérdi éremlelet (Adalékok Baranya megye római kori történetéhez) (Der Münzfund in Szemely und in Pellérd. Beiträge zur Geschichte des Komitates Baranya in der römischen Zeit). JPMÉ 44-45 (1999-2000) 71-78.

= J. FITZ: Gorsium-Herculia im 4. Jh. ActaAntHung 24 (1976) 383-389.

= J. FiTZ: Die Verwaltung Pannoniens in der Römerzeit. I-IV. Budapest 1993-1995.

= J. FITZ (ed.): Religions and Cults in Pannonia. SzIKMK A/33. Székesfehérvár 1998.

= F. FüLEP: Neuere Ausgrabungen in der Römerstadt Sopianae (Pécs). RégFüz II/16. Budapest 1974. patera in his right hand. The inscription of the coin is GENIUS P $R$ KunCKEL 1974, 47, 117, M I 18, Taf. 2.6

${ }^{148}$ PozSÁRKó 1990, 109-118; PozSÁRKó 2004, 272.

${ }^{149}$ In addition, altars provide data about the religious life in Sopianae and to identify the places of temples and shrines of the settlement. Based on the altars unearthed, it is assumed that one of the shrines of legio I. Adiutrix beneficiarii consularis was located on Széchenyi Square. An altar dedicated to Silvanus was also unearthed in this part of the settlement. According to altars unearthed following the path of Rákóczi Road (considered to be one of the main roads of Sopianae) a temple of the Capitolian Triad and a shrine dedicated to Hercules are to be taken into consideration. The location of the Mithraeum, because of the secondary use of the altar stone dedicated to Mithras unearthed in the area, is uncertain: PozsÁRKó 2004, 272.

${ }^{150}$ An detailed interpretation of the inscription see below in the appendix-paper by B. Fabián and Á. Szabó. 
FÜLEP 1984

FRADIER 1976

FRÖHLICH 1991

GALIANO et al. 1986-1987

GÁBOR 2003

HARL 1999

KÁRPÁTI 2004

KÉRDŐ 1985

KIRCHHOF 2011

KIRCHHOF 2014

KISS 1973

KovÁcs 2014

KovALICZKY-TóTH 2014

KovALICZKY 2015

KovALICZKY-TóTH 2016

KUNCKEL 1974

LÁNG 2012

LING 1991

MATtern 2001

MIELSCH 2001

Mócsy 1962

MócsY-FITZ 1990

MrÁv 2015

NAGY 1973

Отто 1910

PARRAGI 1991

PEdRAZ 2006-2007

PIQUeRo 2008

POZSÁRKÓ 1990

PozsÁRKó 2004

RAMAGE 1999

RANIERI PANETTA 2005

REINACH 1922

SABRIÉ-SOLIER 1987
= F. FüLEP: Sopianae. The History of Pécs during the Roman Era. ArchHung 50. Budapest 1984, 1-391.

= G. FradiER: Mosaiques romaines de Tunisie. Tunis 1976.

= T. FRÖHLICH: Lararien- und Fassadenbilder in der Vesuvstädten. Untersuchungen zur ,Volkstümlichen” pompejanischen Malerei. MR Ergänzungsheft 32. Maiz 1991.

= D. F. Galiano-O. D. Trujillo-B. C. Cano: Representaciones del Genio del Año en mosaicos Hispanoromanos. CPA 13-14 (1986-1987) 175-183.

= O. GÁBOR: Lararium Bakonyáról [A Lararium from Bakonya]. Bakonyi Szemle 3 (2003) 2-3.

= O. HARL: Die zweite Weihung an den Genius einer Zenturie aus dem Legionslager Vindobona. Fundort Wien. Berichte zur Archäologie 2 (1999) 6-14.

= G. KÁRPÁtI: The Roman settlement of Sopianae. In: The Autonomous Towns of Noricum and Pannonia. Pannonia II. Eds: M. Šašel Kos, P. Scherrer. Situla 42. Ljubjana 2004, 282-285.

= K. H. KéRDŐ: Budapest III., Dugovics Titusz tér 2. RégFüz I/38 (1985) 36.

= A. KIRCHHOF: Pannoniai villák falfestészete. Doktori disszertáció [Wall-painting in Pannonian Villas. Thesis of the PhD Dissertation, Manuscipt]. Budapest 2011.

= A. KIRCHHOF: Új falfestmények az aquincumi katonavárosból (Előzetes jelentés a Bp., III. ker., Hunor u. 24-26. telken előkerült falfestményekröl) - New wall-paintings come from the Aquincum Military Town. Preliminary report on the wall-paintings from Budapest, III., 24-26. Hunor Street. In: FiRKák III. Ed.: P. Balázs. Szombethely 2014, 113-128.

= Á. KIss: Roman Mosaics in Hungary. FontArchHung. Budapest 1973.

= P. KovÁcs: A History of Pannonia during the Principate. Antiquitas I/65. Bonn 2014.

$=$ G. KovAlicZKY-Zs. TóтH: Pécs római kori településtörténetének vázlata [Draft of the Roman Age settlement structure of Pécs]. Ókor. Folyóirat az antik kultúrákról 2014/1 (2014) 80-91.

= G. Kovaliczky: Régészeti feltárások Pécs, Sopianae téren. Összefoglaló jelentés (Archaeological excavations on the Sopianae Square, Pécs. Summary report). JPMÉ 53 (2015) 71-86.

= G. KovAliczKy-Zs. Tóth: Pécs város történeti atlasza. A kezdetektől napjainkig. 2/3.: Római kor [Historical Atlas of the Town Pécs. From the beginnings to today.]. Pécs 2016.

$=$ H. KunCKEL: Der römische Genius. RM Ergänzungsheft 20. Heidelberg 1974.

= O. LÁNG: Új eredmények az aquincumi polgárváros délkeleti régiójának kutatásában - az úgynevezett Festöház és közvetlen környezete (New results in research in the southeastern part of the Civil Town in Aquincum - the so-called "Painter's House" and its surroundings). AqFüz 18 (2012) 17-36.

$=$ R. LING: Roman Painting. Cambridge 1991.

= M. MATTERN: Götterverehrung im römischen Hessen-Besonderheiten und regionale Einflüsse im Spiegel der Steindenkmäler. BudRég 34 (2001) 177-187.

$=$ H. Mielsch: Römische Wandmalerei. Darmstadt 2001.

= A. Mócsy: Pannonia. PWRE Suppl. IX. Stuttgart 1962, 515-776 col.

= A. MócsY-J. Fitz: Pannonia régészeti kézikönyve [Archaeological Handbook of Pannonia]. Budapest 1990 .

= Zs. Mráv: A Római Birodalom határvidékén (Kr. e. 1. század vége - Kr. u. 5. század eleje) [On the frontier of the Roman Empire - end of $1^{\text {st }} \mathrm{c}$. BC-beginning of $5^{\text {th }} \mathrm{c}$. AD]. In: A Kárpát-medence ösi kincsei a kőkortól a honfoglalásig. Ed.: Á. Vágó, G. Szenthe. Budapest 2015, 3-62.

= T. NAGY: Budapest története az őskortól a honfoglalásig. II. Római kor. [The history of Budapest from Prehistory to the end of the Árpád Era. II.: Roman period]. In: Budapest története az őskortól az Árpád-kor végéig. Ed.: L. Gerevich. Budapest 1973, 83-184.

= W. F. OtTo: Genius. PWRE XIII. Stuttgart 1910, col. 1155-1170.

= Gy. PARRAGi: A Folyamör utcai római villa (Römische Villa in der Folyamőr-Gasse). BudRég 28 (1991) 199-215

= M. P. S. N. PedraZ: Motivos de Xenia en los mosaicos romanos de Hispania. Historia Antigua 19-20 (2006-2007) 469-497.

= J. C. Piquero: La riqueza de las villas de la Meseta a través de los mosaicos romanos. In: L'Africa romana. Le ricchezze dell'Africa : risorse, produzioni, scambi. Atti del XVII convegno di studio, Sevilla, 14-17 dicembre 2006. Ed.: J. Gónzález Fernández. Roma 2008, vol. II, 1263-1273.

= Cs. PozSÁRKó: Beneficiary altar from Sopianae. SpecN 1990 (1992) 109-118.

= Cs. PozsÁRKó: The historiography and epigraphy of Sopianae. In: The Autonomous Towns of Noricum and Pannonia. Pannonia II. Eds: M. Šašel Kos, P. Scherrer. Situla 42. Ljubljana 2004, 270-276.

= N. H. Ramage-A. Ramage: Römische Kunst. Von Romulus zu Konstantin. Köln 1999.

= M. Ranieri Panetta (Hrsg.): Pompeji. Geschichte, Kunst und Leben in der versunkenen Stadt. Stuttgart 2005.

$=\mathrm{S}$. REINACH: Répertoire de peintures grecques et romaines. Paris 1922

$=$ M. SABRIÉ-R. SABriÉ-Y. Solier: La maison à portiques du Clos de la Lombarde à Narbonne et sa décoration murale. Fouilles 1975-1983. RAN Suppl. 16. Paris 1987. 
SALOMONSON 1974

SCHMIDT-COLINET-PlatTNER 2004

SZABÓ 2001

SZIRMAI 1984

THOMAs 1963

THOMAs 1965

TÓTH 2006

То́тн 2008

TóTH 2010

VÁMOS 2008

VÁMOS 2012

VISY 2013

WELLNER 1969

WIRTH 1934

YACOUB 1970

ZIMMERMANN-LADSTÄTTER 2010

ZsIDI 2000
= J. W. SALOMONSON-M. ENNAIFER: Antik mozaikok és műkincsek Tunéziából. Kiállitásvezető [Antique Mosaics and Art Treasures from Tunisia. Exhibition guide]. Budapest 1974.

= A. Schmidt-Colinet-G. A. Plattner: Antike Architektur und Bauornamentik. Grundformen und Grundbegriffe. Wien 2004.

= E. Szabó: Genius. In: Római történeti kézikönyv. Ed.: Gy. Németh. Budapest 2001.

= K. SzIRMAI: Újabb adatok az aquincumi légióstábor falfestészetéhez (Neuere Angaben zur Wandmalerei des Legionslagers von Aquincum). BudRég 25 (1984) 247-253.

= E. B. Thomas: Római kori háziszentély-leletek Tamásiból (Römerzeitliche Hausheilugtümer aus Tamási). A szekszárdi Balogh Ádám Múzeum tudományos füzetei 4. Szekszárd 1963.

= E. B. THOMAs: A nagydémi lararium (Das Lararium von Nagydém). Veszprém 1965.

= E. Tóтн: A pogány és keresztény Sopianae (A császárkultusz-központ Pannonia Inferiorban, valamint a pogány és keresztény temetkezések elkülönítésének a lehetőségeiről: a II. sírkamra) [The Pagan and Christian Sopianae (On centre for the Imperial cult in Pannonia Inferior, and possibilities for the separation of pagan and Christian burials: burial chamber II]. SpecN 20 (2006) 49-102.

= Zs. Tо́тн: Régészeti feltárás 2008-ban Pécsett, a Kossuth téren. Összefoglaló jelentés (Archaeological excavation in Pécs in 2008. A summary). Pécsi Szemle 11 (2008) ösz, 3-19.

= Zs. Тóтн: A Rákóczi út-Jókai utca saroktelken végzett 2008-2009. évi régészeti feltárásról. Adatok Pécs római kori történetéhez. [The archaeological excavation at the corner of the Rákóczi Street and the Jókai Street undertaken in 2008-2009. Details for the history of Roman Pécs]. Pécsi Szemle 13 (2010) nyár, 8-27.

$=$ P. VÁmos: Genius representation from the northern region of the Aquincum Military Town. In: Cultus deorum. Studia religionum ad historiam. In memoriam István Tóth. II.: De rebus eetatis Graecorum et Romanorum. Ed.: Á. Szabó, P. Vargyas. Ókortudományi dolgozatok 1. Pécs 2008, 251-258.

= P. VÁmos: A hely szelleme. Genius-relief mint építési áldozat? - The spirit of place - Genius representation as a form of building sacrifice? In: Firkák II. Eds: Sz. Bíró, P. Vámos. Györ 2012, 361-373.

= Zs. VISY: Sopianae településtörténete [Settlement history of Sopianae]. In: Pécs története. I.: Az őskortól a püspökség alapításáig [History of Pécs I.: From Prehistory to the Foundation of the Bishopric]. Ed.: Zs. Visy. Pécs 2013, 93-152.

= I. WeLlNER: The Hercules villa in Aquincum. ActaArchHung 21 (1969) 241-272.

= F. WIRTH: Römische Wandmalerei vom Untergang Pompejis bis ans Ende des dritten Jahrhunderts. Berlin 1934

= M. YACouB: Le Musée du Bardo. Tunis 1970.

= N. ZIMMERMANN-S. LADSTÄTTER: Wandmalerei in Ephesos von hellenistischer bis in byzantinische Zeit. Wien 2010.

= P. ZsIDI Falfestmények az aquincumi polgárvárosból és a városi territoriumról - Neue Wandmalereien aus der Aquincumer Zivilstadt und vom Gebiet der umliegenden Villen-Zusemmenfassung. In: A római kori falfestészet Pannoniában. Nemzetközi konferencia a pannóniai falfestészet problémáiról - Die römische Wandmalerei in Pannonien. Hrsg.: L. Borhy. ActaArchBrig I/1. Komárom 2000, 132-156. 
